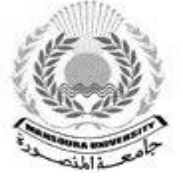

Mansoura University

Faculty of Tourism and Hotels

\title{
Potentials of Agricultural Heritage SYSTEMS TOURISM (AHST): A CASE STUDY OF DATE PALM USES IN GASTRONOMY, SIWA OASIS \\ - EGYPT
}

\author{
By \\ Dr/ Noha Ibrahim khalil \\ Dr/ Eslam Ahmed Fathy \\ Associate Professor Faculty of Tourism \\ Associate Professor Faculty of \\ and hotels Department of Tourism- \\ Matrouh University, Egypt \\ Tourism and Hotel Management \\ Hotel Management Department- \\ Pharos University
}

\section{RESEARCH JOURNAL OF THE FACULTY OF TOURISM AND HOTELS MANSOURA UNIVERSITY \\ ISSUE NO. 10, DECEMBER. 2021}


Potentials of Agricultural Heritage Systems

Tourism (AHST): A case study of date palm uses in gastronomy, Siwa Oasis - Egypt 


\title{
Potentials of Agricultural Heritage Systems Tourism (AHST): A case study of date palm uses in gastronomy, Siwa Oasis - Egypt
}

\author{
Dr. Noha Ibrahim Khalil \\ Associate Professor Faculty of Tourism \\ and hotels \\ Department of Tourism-Matrouh \\ University, Egypt.
}

\author{
Dr. Eslam Ahmed Fathy \\ Associate Professor Faculty of Tourism \\ and Hotel Management \\ Hotel Management Department-Pharos University
}

\begin{abstract}
:
The main objective of the current study is to develop a strategy for the Agricultural Heritage Systems Tourism (AHST) pattern. The strategy aims to maintain sustainability of The Globally Important Agricultural Heritage System of Siwa through date palm uses in tourism and hospitality. The strategy is incorporating the triangular relationship between cuisine, product and territory. The current study employed a semi-structured interview in order to obtain the most accurate results through two samples; the first is purposeful and the second is convenient. The study indicated that (AHST) will support preservation of (GIAHS). The results also indicated that (AHST) will enhance the livelihood of the local community of Siwa as well as most of the sustainable development goals (SDGs). The results also showed that the uses of date palm in tourism and hospitality are limited, whether on or off farm. It is only used for drinks and desserts, and farms do not have sufficient facilities to receive tourists. The proposed strategy will enhance cooperation among stakeholders in order to enrich gastronomy tourism experience and to achieve (AHST) through the uses of date palm in food menu items and in other tourism and hospitality activities. Key words Globally Important Agricultural Heritage systems (GIAHS), Agricultural Heritage Systems Tourism (AHST), Date Palm uses, Gastronomy, Siwa.
\end{abstract}


Potentials of Agricultural Heritage Systems

Tourism (AHST): A case study of date palm uses in

gastronomy, Siwa Oasis - Egypt

\section{Introduction}

The initiative of The Globally Important Agricultural Heritage Systems (GIAHS) was launched by Food and agriculture organization (FAO) in order to safeguard the remarkable agricultural heritage sites through many long-term programs and support such systems in order to enhance sustainable development. Under the adoption of the 2030 Agenda for Sustainable Development, there are seventeen Sustainable Development Goals (SDGs), and tourism has potentials to contribute to all the goals (UNWTO,2018; FAO,2018; UNDP,2018). The designation goes beyond merely identifying (GIHAS) and transforming them into many attractive tourist destinations with great economic, socio-cultural and environmental impacts (Sun,Y.H. et.al.,2013; Mi et.al., 2014; Tian et.al,2016). The World Tourism Day 2020 affirmed the role of tourism in the recovery of the rural areas from the impacts of the COVID-19 breakdown. So that FAO and UNWTO work together to promote agri-tourism at (GIAHS) sites; where tourists can experience the natural landscapes, the agricultural practices and cultural heritage (UNWTO,2020a; FAO,2020a). In general, Agri-tourism is an alternative source of revenues and heritage preservation in rural areas where agricultural activities and tourist come together. It includes various farm activities and accommodation at the rural surroundings with the local cuisine. (Sullins, Moxon, and McFadden, 2010; Srivastava,2016; tompkinscountyny,2016; Khangarot and Sahu,2019).Either organic or prepared food can be incorporated in agri-tourism in order to enhance sustainable practices of tourism and agri-food sector through the gastronomic experience (Sidali, Spiller and Schulze 2011;sun et.al.,2011). Using creative Agricultural food products provides tourists with an authentic sense of place, links them to the farms life community and revives agricultural heritage of the destination (Coelho, Coelho and egerer,2018; Ammirato et.al.,2020). Since 2005, FAO has designated sixty two agricultural heritage systems in twenty two countries and Siwa oasis was designated in 2015 (FAO). The economic entanglement between agriculture and tourism sectors is limited as well as the economic benefits for the local community that is the key stakeholder in sustainable tourism development by sharing 
their heritage with visitors. (Tian,2016; Su et.al, 2018). Furthermore, local executive chefs of siwa have a low level of culinary skills, due to the low educational level and lack of training programs which can threaten the creativity of the culinary art. Consequently; agri-tourism will provide economic, educational, and social benefits to all stakeholders; date palm producers, chefs, tourists, communities as well as incentives for producers to remain in agriculture. (Abdel Rassoul and Fathy, 2019; FAO,2020). In other words, promoting farm tours and creative recipes in restaurants are challenging matters both for the hoteliers or the owners of date palm farms in Siwa. The objective of the current study is to investigate the potentials of (AHST) in these unique sites. This could be achieved through the creative uses of date palm in tourism and hospitality such as farm activities, food menus, furnishing and decorations of restaurants. The questions of the study are as follows; First; What are the current uses of date palm in tourism and hospitality in Siwa? Second; what are the impacts of the creative uses of date palm in tourism and hospitality on sustainability of Siwa as one of (GIAHS) and what is the appropriate strategy? In the literature of tourism there has been no comprehensive assessment of the role of tourism in sustainable development of (GIAHS) in comparison to the World Heritage Sites (WHSs); so that the current study provides theoretical and practical implications for promoting Siwa as (AHST) destination and maximizing the macroeconomic impacts for the owners of the date palm farms and other tourism providers. 
Potentials of Agricultural Heritage Systems

Tourism (AHST): A case study of date palm uses in

gastronomy, Siwa Oasis - Egypt

\section{Literature Review}

The Globally Agricultural Heritage System (GIAHS) and Agricultural Heritage System Tourism (AHST)

The Globally Important Agricultural Heritage Systems (GIAHS) initiative was established by the Food and Agriculture Organization of the United Nations (FAO) in Johannesburg 2002 during the World Summit on Sustainable Development (WSSD) aiming to conserve these systems. The designation of sixty- two sites in twenty two countries was based on five criteria; Food and Livelihood Security, Cultures, Value systems and Social Organizations, Landscapes and Seascapes Features Local and accumulated traditional knowledge systems and Agro-biodiversity (FAO; Koohafkan, 2009; Vafadari,2013; Tian,et. al 2016; FAO,2017; UN). The concept of (GIAHS) is more complex than the common concept of heritage sites. It connects the living active agricultural systems with cultural heritage which is related to the territory usages, methods and production through the role of agriculture. In other words, when agriculture is practiced in a sustainable way, it can preserve and integrate both the environment and the livelihoods of the local communities especially small-scale family farmers who practice the agriculture based on traditional knowledge in line with (SDGs).(Altieri and Koohafkan,2003; Daugstad, Rønningen and Skar,2006; $\quad$ FAO;UN; $\quad$ orldagriculturalheritage; griculturalheritage;ouik).Consequently, FAO will empower these communities to use their local assets for income-generating by implementing action plans focusing on benefiting the local people through sustainable agri-tourism. In other words, Agricultural tourism is one of the most important means of achieving this goal (clintonfoundation; Fuller et.al,2015).In 2020, Covid-19 impacted these systems because of the decrease of demand for agricultural products as a result of recession of tourism and hospitality industry as an alternative source of income in hotels and restaurants, which led to increased unemployment, lower income, and lower prices of agricultural products in supply chains either on or off- farm levels. (FAO 2020a; Morales et.al.,2020; ouik). The World Tourism Day 2020 highlighted the important role that tourism can play in 
preserving and promoting agricultural heritage around the world (UNWTO,2020 b). The FAO-UNWTO Partnership have been made in order to promote agri-tourism in FAO's (GIAHS) sites through combining traditions and innovation in using agricultural products related to the farms, food products and handicrafts (FAO,2020b). Kunisaki peninsula, Japan, the traditional rice-fish system at Qingtian in Zhejiang province of China, and Xuanhua Grape Garden, Hebei Province of China demonstrated the impacts of tourism on increasing the price of agricultural products and enhancing the recognition of the value of traditional agricultural systems. Consequently, conservation of the traditional agricultural systems could have a share of rural, eco, cultural tourism and food tourism market. As a result, it is vital for sustainable tourism development and heritage preservation (Fuller,et.al.,2015 Tian,2016; Ruoss, 2017; su,2018; worldagriculturalheritage). In the circumstances of the COVID-19 pandemic, agri-tourism areas will be more effective in sector's recovery because that tourists look for the natural, less crowded, ecodestinations and open-air trips in a sustainable manner environmentally, socially and with fair economic benefits especially for women empowerment and gender equality and greener approach in all travel stages (UNWTO,2021).

Tourism in the agricultural heritage systems can be classified as (AHST). The focus of AHST is heritage and preservation of biodiversity and indigenous lifestyle of agricultural heritage sites through tourism. In other words it is an integrated relationship among tourism, community and their culture and heritage (Tian, et.al 2016; Chauhan,2020). The Ifugao Rice Terraces, Philippines, is an example of harmonized humankind and environmental sites; it is one of (GIAHS) and a World Heritage Site with a history of more than 2000 years ago. There are many other examples for (AHST) applications such as Satoyama and Satoumi, Japan, Soave Valley vineyards, Italy, Chiloé Agriculture, Chile and Rice Terraces in Southern Mountainous and Hilly areas, China and Longxian village, situated in Zheiiang Province, southern China (worldagriculturalheritage; Sun et.al., 2011; FAO; Hong et.al.,2013; Vafadari, 2014; Tian, et.al 2016; FAO,2020b).In June,2021, FAO and International Council on Monuments and Sites (ICOMOS) and the International Union for Conservation of Nature (IUCN) issued a report about the Connecting 
Potentials of Agricultural Heritage Systems

Tourism (AHST): A case study of date palm uses in gastronomy, Siwa Oasis - Egypt

Practice Project which aims to the conservation and raising awareness with the interrelationship of natural and cultural dimensions of three of the world heritage sites and (GIHAS); Al Ain and Liwa Historical Date Palm Oases, United Arab Emirates and Hani Rice Terraces, China (FAO,2021). (AHST) is a tool for sustainability, it can create jobs, enrich local culture, human resources, and physical accommodations, roads, car parks, restaurants and public utilities (Valdivia and Barbieri,2014). In Qingtian County, China, tourism income and the reduced price of rice contribute for eliminating poverty (SDG1) and zero hunger (SDG2) and job creation achieving SDG 8 (FAO). This tourism pattern has the ability to link between agricultural system and ethnic groups, archaeological and religious buildings, social practices, oral traditions and performing arts and festival events. It could also establish cultural awareness, maintain the identity of the destination, sense of place and the livelihood patterns. (Tian, et.al., 2016).

\section{Gastronomy and sustainable tourism development}

Gastronomy tourism can become an activity supporting destinations and a determinant element of sustainable development of places. Gastronomy tourism also increases destinations' attractiveness and competitiveness by either trying local dishes of an area or observing production (Sormaz, et.al., 2016; Rinaldi,2017). Gastronomy tourism broadens the view through presenting gastronomical heritage, either regional food or organic food. (Sidali, Spiller and Schulze,2011; UNWTO,2017). Gastronomy is the primary prerequisite for the development of authentic agri- tourist experience; consequently, GIAHS are one of the most important places where gastronomy tourists can experience local food and beverages. Thus, the inclusion of agricultural producers, markets, craftsmen construct the identity and authenticity of the place and enrich value of the destination. (Grigorova, Shopova, and Timareva,2016; UNWTO,2017; Sorcaru, 2019; Testa et.al., 2019).

The collaboration between GIAHS Program and Slow Food Foundation promotes the agricultural systems and their products. As a part of this collaboration, the producers from Guinea-Bissau, Mali, Senegal and Sierra Leone presented their products at Slow Food's International Salone del Gusto/Terra Madre event in Turin, Italy, in October 2012. There have been overall increases in the production 
volume, income, and market opportunities. In other words, promoting traditional food products linked to the origin stimulates the startups in hospitality and food industries (FAO) Consequently, Gastronomy tourism not only contributes to the conservation of biodiversity and landscapes of rural areas, but also supports the continuity of its population and preserves tangible and intangible heritage and the recovery of culinary memory. Thus, Gastronomic experience of tourist in Siwa could empower all parties of the gastronomic value chain, especially local community and producers of date palm. It will support the sustainability of (GIHAS) and the related tourist activities, diversify their economies and create new demand for their agricultural products (Harvey,2012; Vafadari,2013; UNWTO,2017; FAO,2019; FAO,2020b). 
Potentials of Agricultural Heritage Systems

Tourism (AHST): A case study of date palm uses in gastronomy, Siwa Oasis - Egypt

\section{Siwa oasis as an Agricultural Heritage Systems tourist destination}

Siwa oasis is located in Matrouh governorate, northwestern of the Egyptian Desert, $80 \mathrm{~km}$ from the Egyptian borders with Libya and $300 \mathrm{~km}$ south of the Mediterranean with a total area of 1372 $\mathrm{km} 2$.It is situated in an extremely arid desert climate. It is inhabited with 28,300 persons and the primary income source is agriculture of date palm and olive and related Industries (Fig.1). Siwa Oasis is surrounded with unique geomorphologic features, flora and fauna, so that it has been declared Siwa Protected Area. It maintained both the uniqueness of the environmental and cultural value system and the assets of the traditional society such Siwi language, craft production, mud-salt brick architecture and rich heritage performances inside the tribes (Fig.2) (FAO,2016; EL Hadad and Ibrahim,2017; FAO; FAO,2018). As stated, Siwa has a variety in tourist attractions; so that it could be considered as an archeological, ethnic, cultural/heritage, curative, and Eco and safari destination (Amara,2007; Abd Elghani,2012; Egyptian tourism Authority; www.eeaa.gov.eg; Halawa,2016; UNESCO, 2019). In October 2016, and during the Egyptian Date Palm Festival Siwa was designated as one of (GIAHS) (ideassonline; FAO,2016).(GIAHS) designation has the potential to attract tourists and the sustainability of the rural development through agri-tourism (Yotsumoto and Vafadari, 2020).

The criteria were fulfilled as follows; First, food and livelihood security, means that agriculture is the most important economic activity generating jobs, nutrition and local income. There are more than 280,000 date palm generating about 25,000 tons of date yearly, as $2 \%$ of Egypt's total date production. Siwa is also a national olive producer; both of them are representing $93.4 \%$ of the cultivated area. Second, Biodiversity and ecological functions, and this indicates that Siwa has a variety of vegetables, fruits and varied species of high quality date palm, olive and other crops, birds animals and livestock (Fig.3). Third, Knowledge systems and adapted technologies mean that Siwan farmers have a very rich knowledge regarding the harvest, postharvest products and the maintenance of the date palm trees (Samy,2014; Abdul Ghafar,2014; laboasis) (Fig.4). The fourth criterion is related to 
Cultures, value systems and social organizations, it means that they have a unique intangible cultural heritage and special characteristics of cultural manifestations such as dancing, date palm festival (called "AlSeiaha") which occurs in October (Fig5.). There are also many creative industries such as the architecture of mud brick and the historic craft production like silver jewelry, knitting and needle works, basketry woven items from palm frond (Fig.6). "Qabila" or tribe is the asset of the traditional society of Siwa and the majority of Siwans are Berber with unique customs and traditions. Their language is Siwi and it borrows some Arabic words. (siwa-oasis.it; Abul Hawa, et.al., 2007; Nofal,2011; Saleh; 2017; FAO,2016; Asham,2019). Finally, remarkable landscapes, land and water resources management, indicate that the oasis looks like surrounding desert, including few patches of many sparse natural species of plants relying only on the natural springs (Fig.7). The irrigation method in Siwa is the simple traditional surface irrigation by the gravity in the small basins, it is described as a low energy method. Closing and opening of water to the plots of the individual farmers are precisely timed schedules by the leaders of the society (FAO,2016; Hasan, 2016; Moghazy and Kaluarachchi, 2020). Consequently, Siwa could be an Agricultural Heritage Systems Tourist destination depending on the living heritage of date palm on- farm and off-farm.

\section{Methodology}

The objective of this study is to explore the current and the potential uses of date palm in tourism and hospitality in Siwa. The two sample groups, owners of date palm farms and executive chefs, have a vital role in enriching the economic entanglement between agriculture and tourism sectors through innovative uses of date palm in tourism and hospitality which may contribute to the sustainability of Siwa as one of (GIAHS). The researchers used the qualitative approach due to the limited studies in this research area. The study used the semi-structured interview in order to gain reliable and beneficial qualitative data that can be used for the deep understating of threats and opportunities of Agricultural Heritage Systems Tourism (AHST) in Siwa. Initially, the current study recruited a pilot study conducting five in-depth semi-structured interviews for each sample in order to avoid misleading and unnecessary questions and keeping the questions short and specific. The pilot study was conducted in 
Potentials of Agricultural Heritage Systems

Tourism (AHST): A case study of date palm uses in gastronomy, Siwa Oasis - Egypt

February 2020 before the first wave of the spread of Corona Virus in Egypt. The final version of the interview questions was launched and after the interviewees permission, the researchers recorded all face to face and phone calls in order to apply the precautionary measures of social distancing during the circumstances of Covid-19, and then transcribed verbatim. The interviews were conducted using clear and easy to understand closed and open-ended questions but not leading to bias. The interview included four parts, First, the warm-up part explained the study objectives whereas the second was for the demographics. Third part, was about the current uses of date palm in hospitality and tourism on farm and off- farm. Finally, the last part included the potential innovative uses of date palm in tourism and hospitality. The interviewers affirm the confidentiality of the responses and the fidelity of using them in scientific purposes then they thanked the participants for their time. Several factors were taken into consideration during the interview, such as postures, gestures, voice tone and eye contact in order to get the demanded information. The researchers were careful not to interrupt the interviewees or writing notes during the interview so as not to worry them as well as to stick to time.

The questions were developed from tourism literature and the pilot study that suggested new questions not mentioned in literature. The researchers sent the interview to some academics. All the interviews were conducted in Arabic and the duration of each interview ranged between 30 and 50 minutes. Purposeful sampling was used for the owners of date palm farms $(n=35)$. The interview was conducted during and immediately after the harvest season in October and November 2020 (Fig.8). This sample was designed according to the potential of farms to benefit from tourism and hospitality activities which is interpreted in the age of the farm which is not less than 15 years, the farm space of not less than five acres and bio- diversity inside farms. As for executive chefs, who are responsible for planning and design menus; Convenience sampling was conducted in Siwa hospitality sector. Selection was about what are close at hand and easy to get access to them $(n=45)$. Those types of improbability samples are suitable for such a qualitative study for the identification and selection of information-rich case. (Palinkas et.al.,2013; Patton, 2015; Elmusharaf,2016). 


\section{Results and discussion}

\section{The owners of date palm farms perceptions of the} impacts of Agricultural Heritage Systems Tourism (AHST)

All the owners of date palm farms have a great knowledge about Siwa as one of (GIAHS). They grow date palm organically and irrigate naturally and they are also using advanced techniques to serve date palm. They indicated that agriculture is the vital economic activity with regard to date palm and olive. There are varieties of fruits beside date and olives such as pomegranate, oranges, figs, guavas, grapes and lemons, which enhance biodiversity. All of owners of the farms believe that tourism can sustain the agricultural heritage system, create jobs and increase their income. These results indicated to the high awareness among the interviewees about siwa as one of (GIAHS). This can be implemented for the development of Siwa as an AHST destination and for gastronomy tourism especially for the food items that made of date palm. This can also be implemented by launching many tourist activities such as "The Harvest Week" and " The Rural Days". They indicated that food security and economic entanglement between tourism and agriculture can be achieved by reviving the traditional food items that made of date palm as well as the innovative. Consequently, they also recognized that date palm could be a brand for Siwa as (AHST) destination. It could also make it a distinctive tourist destination for gastronomy tourism. It can also help to achieve the agricultural identity of Siwa as a tourist destination. Most of the owners of the farms asserted that tourism can be a propulsive force for agriculture; through buying fertilizers or using the advanced techniques to serve the palm. These results confirms that gastronomic experience can achieve many of (SDGs) in Siwa as one of (GIAHS).

\section{The on-Farm current uses of date palm}

Most of the owners of date palm farms indicated that their farms haven't many of the required facilities to receive tourists and as $\mathrm{Mr}$. Yousef Addoul, one of the owners of the farms, he said " Visits are limited to scientific purposes of agricultural researchers and this is the first time to receive tourist and hospitality researchers". He added "I wish to receive tourists in my farm in order to taste the varied species of date I cultivate but it needs more facilities such as accommodation, restaurant 
Potentials of Agricultural Heritage Systems

Tourism (AHST): A case study of date palm uses in

gastronomy, Siwa Oasis - Egypt

and gift shop". There is a limited number of farms that have tourist facilities such as camps which contains lodging, restaurant, café, gift shops, hot springs and Folkloric concerts such as the camp of Ali Khaled.

\section{The potentials of tourist uses of date palm}

The owners of the farms of date palm agree to operate their farms partially to be for tourist visits and they expressed their need to make deals with travel agents to organize day trips or overnights. They stated that farms should be equipped with palm leaves and stalks, free parking, and hot springs (Fig.9), free Wi-Fi and a gift shop for selling raw and processed date and souvenirs. One of them wishes to organize cooking workshops for traditional food and another one also wishes to participate more in palm date events as he said "I never participated in date palm festival." Mr. Youssef Adoul, an iconic owner of a date palm farm, indicated that he is the recipient of the prize of the best farms Nakheel owns multiple varieties of date palm, numbering up to 35 species and that was on the second session of the Egyptian Date Festival. The prize was presented by the Khalifa International Award for Date Palm and Agricultural Innovation for the year 2016. During this period Siwa was celebrated for its designation as one of (GIAHS). $\mathrm{He}$ also participated in preparing Atlas of Egyptian date with FAO. He prefers to organize rural days for visitors to the farm in order to taste his varieties. Among the most important types of his production of date are the "Aquarium" "Al Barhi" "Deglanor" "Al "Majdool" "Dushk Jbeil" "Sawabi Al Arousa" "Zawag Ablann" (EL Sharabasy and Rizq,2019) (Fig.10). Another farm owner wishes to have an eco- lodge rooms in his farm, and other one wants to make tourist competitions in siwan local food. Based on above, the potential uses of date palm depend on two basic elements, the amenities of the farms and the on-farm tourist activities.

\section{The executive chefs perception of AHST impacts}

Fortunately, the executive chefs perceive that sustainability of Siwa as one of GIAHS will be achieved through reviving traditional and modern recipes made of date palm in hotels and restaurants. They stated that date can promote gastronomy tourism in Siwa in addition to affirming the agricultural identity of Siwa as a tourist destination, which enables date palm to be a brand for marketing restaurants, hotels, or the destination of Siwa. They agreed that uses of date palm in tourism and hospitality will achieve 
sustainability through the food security, biodiversity, job opportunities and increasing income at micro and macro levels.

\section{The off-farm Current uses of date palm in hospitality}

All the executive chefs said that their restaurants offer items made from date and use date palm trunks and leaves in the furniture and décor of hotels (Fig.11) and restaurants. (Fig.12). They stated that food items are often limited to some drinks and desserts. The executive chefs stated that international tourists prefer to taste traditional food made of date palm but because of Covid-19 they are few. On the contrary, the domestic tourists prefer western desserts containing date. Most of the executive chefs are not educated in hospitality institutions and this could be a leading indication that the ability to design complete menus of innovative food items of date palm, such as appetizers, salads, soups meat items as a main dish, pastries, bakery, and fabricated date, depends on the high level of specialized education or talent of innovation. Most of them indicated that there is no special menu for traditional food items of Siwa in all restaurants and they have no role in designing the menus except for three of the executive chefs. Chef Mohamed Al Maghribi, Chef of Taziri Hotel, he is not hospitality-educated but he is very talented where he said, "I am the menu and I use date in many items". Chef Ahmed, one of the hospitality- educated chefs, The chef of Shahrazad Cafeteria has invented a number of items that are not only Desserts such as pizza, salad (tomatoes-onions-peppers- date+ mayonnaise and molasses), date tart, custard with date, and he indicated that the type of" Frehee" date can be used in non-sweet items such as pizza, while "Bashair" date is used in sweets (Fig.13). It is worth noting that talented executive chef of Thales Hotel is the owner and during the interview, she suggested that date could be added to rice instead of raisins. In addition, Omran, the owner of the farm of Fatnas presents date and milk juice and make craft products made of date palm leaves. He stated that he has also tried to present "Basis" and "Tegellantini" as authentic siwan food items three years ago but he stopped because of the limited demand (Fig.14).

\section{The potential uses of date palm in hospitality}

Only a minority of the executive chefs are aware of classifying Siwa as one of GHIAS and most of them indicated their willingness to attend culinary art workshops about the uses of date 
Potentials of Agricultural Heritage Systems

Tourism (AHST): A case study of date palm uses in gastronomy, Siwa Oasis - Egypt

palm. The main challenge of using date in cooking is their perception that the date using is limited for desserts not for salads or meat dishes. This result confirms that they need more training for using date in cooking. These results mean that some of the chefs are enthusiastic to be creative in food menus by using date. UNWTO Secretary-General said "Innovation is a means to promote better tourism products, generate opportunities, create jobs and foster sustainability through gastronomy tourism" (UNWTO,2019).

\section{The implications of the study}

In the frame work of promoting (AHST) as a promising tourist pattern in a sustainable manner; the current study developed a strategy for maximizing the uses of date palm in tourism and hospitality activities as follows:

Vision Achieving sustainable development of Siwa as one of (GIAHS).

Mission Representing the identity of Siwa as an (AHST) destination through creating a unique/authentic tourist product by raising the readiness of the partners for linking tourist activities with date palm agricultural products.

goals-Setting tourism as propulsive force for the agricultural sector in Siwa.

-Maintaining heritage, culture and lifestyle based on date palm.

\section{Objectives}

- Diversification of the existing tourist product of Siwa.

- Expanding the international and domestic Siwan tourist markets.

- Promoting date palm food items in tourism and hospitality sector.

- Pumping new sources of income for farmers' income with a new stream through tourism industry.

\section{The targeted tourism markets}

- Rural/agri- tourism market includes (recreation like hiking, palm date picking, food source watching such as palm, trees or livestock-gastronomy of the varied types of date or dishes of date -industrial tourism such as handicrafts and food industries).

- Heritage tourism market (tangible/intangible agricultural heritage Nostalgia for domestic tourists' roots).

- Educational tourism market (The agriculture science- The cultivation methods). 


\section{The organizational structure}

Establishing an independent body called "The Date Palm Uses Development Authority" in order to co-ordinate all efforts of the partners in the mainstream of implementing the proposed programs in a way that strengthens the economic entanglement between tourism and agriculture sectors without private sector monopolistic practices or the negative environmental, cultural or economic impacts.

\section{The partners}

\section{The governmental Organizations}

Matrouh Governorate /Ministry of agriculture/ Ministry of Tourism and antiquities/ Regional Authority for the Promotion of Tourism/ The Federation of Egyptian Industries.

The national/Regional and International Research centers and technical support

- Matrouh University (faculty of tourism and hotels/ faculty of desert and environmental agriculture)

- Arab Organization for Agricultural Development/ (FAO)/ Agricultural co-operatives of siwa.

\section{The financial organizations}

Agricultural Finance Institutions in Egypt (Bank for Development and Agricultural Credit)

The producers and service providers (Private sector)(the owners of date palm farms/local restaurants/souks and factory owners).

The Egyptian Tourism Federation (Egyptian Travel Agents Association(E.T.A.A)/ Egyptian Hotel Association (E.H.A). 
Potentials of Agricultural Heritage Systems

Tourism (AHST): A case study of date palm uses in gastronomy, Siwa Oasis - Egypt

\section{The marketing Partners and event's organizers}

Egyptian Authority for Tourism promotion/ State Information Service (SIS)/The Egyptian Executive chefs Association/ Cooking channels such as CBC Sofra.

\section{The duration:}

From one year to five years.

\section{Table.1Assessment of the current situation (SWOT analysis)}

\begin{tabular}{|c|c|}
\hline Strengths & Weaknesses \\
\hline $\begin{array}{l}\text {-Location (Easily accessible). } \\
\text {-Rich Natural assets of date palm. } \\
\text {-Rich cultural / heritage and } \\
\text { religious assets of date palm. } \\
\text { - Variety in tourism attractions. } \\
\text { - High Awareness of owners of the } \\
\text { date palm farms of the } \\
\text { designations of Siwa as a } \\
\text { (GIAHS). } \\
\text { - Willingness of owners of the date } \\
\text { palm farms to diversify farm } \\
\text { tourist activities. } \\
\text {-chefs readiness for creativity in } \\
\text { food items using date palm. } \\
\text {-Initiatives of creativity of palm } \\
\text { dates food items. } \\
\text {-Local/authentic food items from } \\
\text { date palm. } \\
\text { Opportunities } \\
\text { - The designations of Siwa as a } \\
\text { (GIAHS) } 2015 \text {. } \\
\text { - The inclusion of 'The Palm: } \\
\text { Knowledge, Skills, Traditions } \\
\text { and Practices' in the UNESCO } \\
\text { Representative List of the } \\
\text { Intangible Cultural Heritage of } \\
\text { Humanity } 2019 . \\
\text {-FAO's Strategy for the }\end{array}$ & $\begin{array}{l}\text { - Poor infrastructure. } \\
\text { - Power imbalances between government and local } \\
\text { community. } \\
\text { - No Engaged, collaborative stakeholders. } \\
\text { - No syndicate for date palm producers. } \\
\text { - Very limited tourist and hospitality facilities in } \\
\text { farms. } \\
\text { - Limited contact of owners of the date palm farms } \\
\text { with travel agents. } \\
\text { - Chefs perceptions of limited usage of date palm in } \\
\text { food items (only sweets and drinks). } \\
\text { - Low Awareness of chefs of the designations of } \\
\text { Siwa as a (GIAHS). } \\
\text { - Lack of culinary education among siwan chefs. } \\
\text { - Lack of agricultural education among siwan owners } \\
\text { of the date palm farms . }\end{array}$ \\
\hline
\end{tabular}




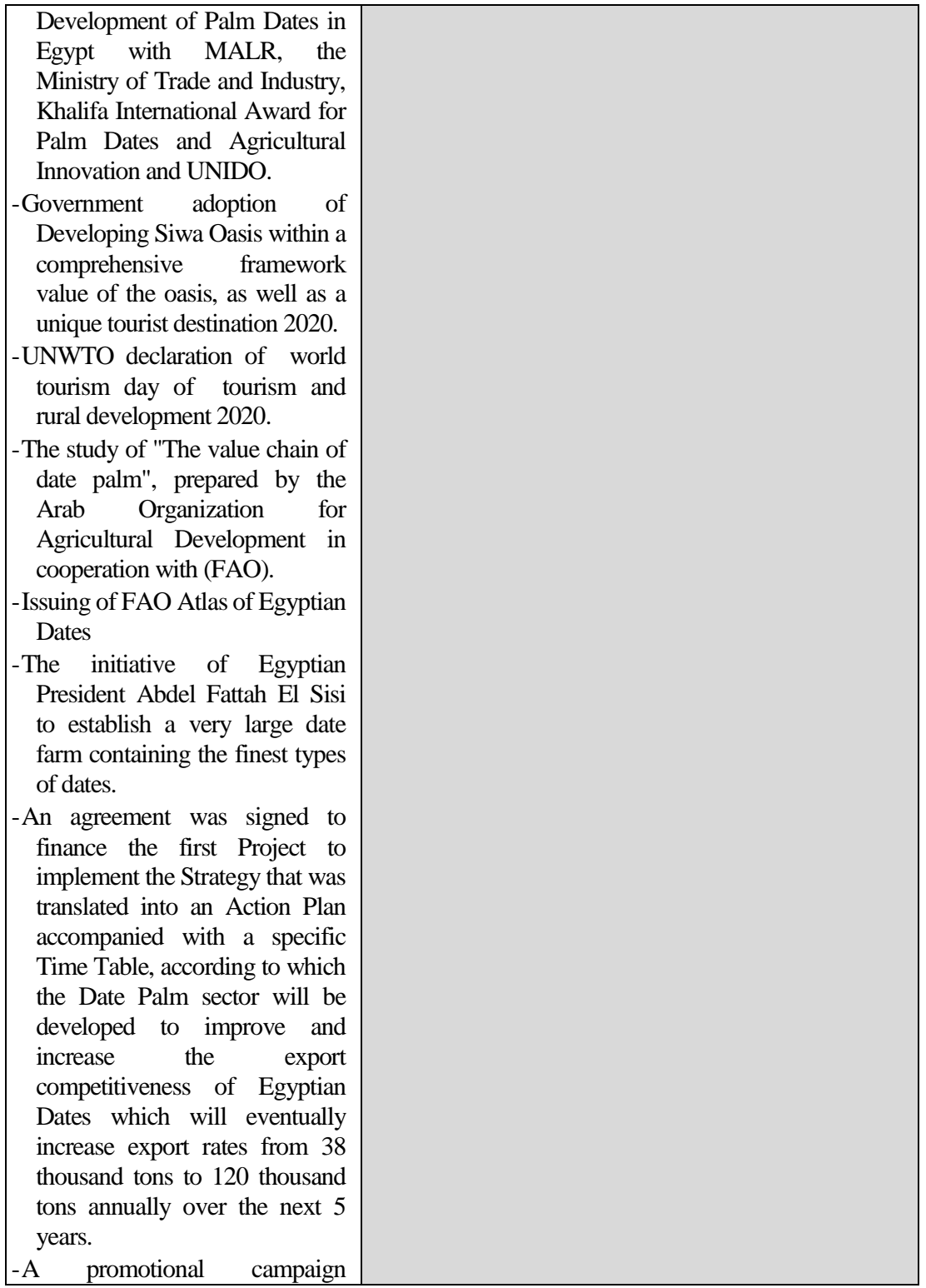




\begin{abstract}
between Egyptian ministry of agriculture and FAO for a digital application entitled "Beneficial in Food and Agriculture", with the aim of strengthening the extension services provided to farmers and rural women.

-Development of the new Egyptian countryside (east of siwa).
\end{abstract}

Source: Adapted from the literature and the field study. 
Table.2 Action plan

\begin{tabular}{|c|c|c|c|c|}
\hline Programs & Tactics & $\begin{array}{c}\text { Implementation } \\
\text { mechanisms }\end{array}$ & Partnership & Outputs \\
\hline \multirow{3}{*}{ 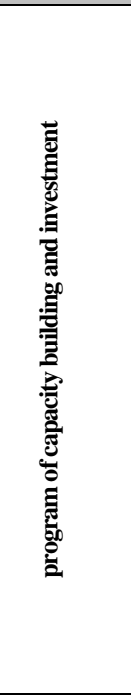 } & $\begin{array}{l}\text { Raising } \\
\text { awareness of } \\
\text { chefs, owners of } \\
\text { the farms and } \\
\text { craftsmen and } \\
\text { women about } \\
\text { the economic, } \\
\text { tourist and } \\
\text { heritage } \\
\text { importance of } \\
\text { date palm. }\end{array}$ & $\begin{array}{l}\text { Informative/educative } \\
\text { workshops/educational } \\
\text { seminars in a training } \\
\text { center } \\
\text { - Conferences about } \\
\text { date palm uses in } \\
\text { tourism and creative } \\
\text { economy. } \\
\text { development of agri- } \\
\text { tourism researches. }\end{array}$ & $\begin{array}{l}\text { - Chamber of Food } \\
\text { Industries. } \\
\text { - Egyptian Tourism } \\
\text { Federation. } \\
\text { - Matrouh University } \\
\text { (faculty of tourism } \\
\text { and hotels/ faculty of } \\
\text { desert and } \\
\text { environmental } \\
\text { agriculture) }\end{array}$ & $\begin{array}{l}\text { Readiness for } \\
\text { creativity in uses } \\
\text { of date palm in } \\
\text { tourism } \\
\text { hospitality and } \\
\text { creative } \\
\text { industries }\end{array}$ \\
\hline & $\begin{array}{l}\text { training farmers, } \\
\text { chefs and } \\
\text { women in uses } \\
\text { of date palm } \\
\text { (souvenir } \\
\text { production - } \\
\text { incorporating } \\
\text { date palm in } \\
\text { recipes) }\end{array}$ & $\begin{array}{l}\text { - Farmers/chefs } \\
\text { /craftsmen and women } \\
\text { networks. } \\
\text { - Preparing a guide for } \\
\text { the appropriate uses of } \\
\text { different types of dates }\end{array}$ & $\begin{array}{l}\text { - Egyptian Executive } \\
\text { chefs Association. } \\
\text { - Egyptian Tourism } \\
\text { Federation. } \\
\text { - Matrouh University } \\
\text { (faculty of tourism } \\
\text { and hotels/ faculty of } \\
\text { desert and } \\
\text { environmental } \\
\text { agriculture) }\end{array}$ & $\begin{array}{l}\text { Empowerment } \\
\text { of human } \\
\text { resources }\end{array}$ \\
\hline & $\begin{array}{l}\text { Farms, Hotels } \\
\text { and restaurants } \\
\text { financing } \\
\text { opportunity with } \\
\text { tax exemption } \\
\text { for one three } \\
\text { years }\end{array}$ & $\begin{array}{l}\text { Fund for date palm uses } \\
\text { in infrastructure and } \\
\text { refrigerators }\end{array}$ & $\begin{array}{l}\text { - Arab Organization for } \\
\text { Agricultural } \\
\text { Development. } \\
\text { - FAO } \\
\text { - Agricultural co- } \\
\text { operatives. } \\
\text { - Matrouh Governorate } \\
\end{array}$ & $\begin{array}{l}\text { Increasing } \\
\text { productivity of } \\
\text { small investors } \\
\text { and startups }\end{array}$ \\
\hline 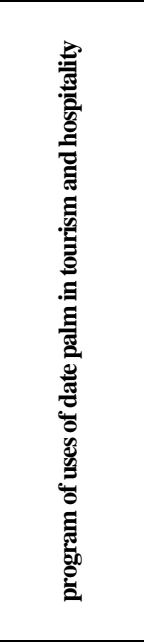 & $\begin{array}{l}\text { Developing } \\
\text { pattern of } \\
\text { AHST (on farm- } \\
\text { off farm) }\end{array}$ & $\begin{array}{l}\text { Agri-gastronomy } \\
\text { activities - Date palm } \\
\text { creative menus } \\
\text { (traditional /new items see } \\
\text { table 3). } \\
\text { - Festival of Siwa } \\
\text { lanterns in Ramadan } \\
\text { (health lectures / date } \\
\text { selling exhibitions) } \\
\text { - Festival "tasting siwa } \\
\text { "Cuisine } \\
\text { competitions/cooking } \\
\text { education). } \\
\text { Agri-relaxation/sports } \\
\text { /recreation activities } \\
\text { - Date palm oases route. } \\
\text { - Rural day and date } \\
\text { palm picking (Fig.15). } \\
\text { - Harvest week. } \\
\text { - competitions of palm } \\
\text { climbing. } \\
\text { Creative industries } \\
\text { activities } \\
\text { - Date palm crafts } \\
\text { competition and fairs. } \\
\text { - Reviving the } \\
\end{array}$ & $\begin{array}{l}\text {-Egyptian Tourism } \\
\text { Federation } \\
\text {-Egyptian Authority for } \\
\text { Tourism } \\
\text { promotion(E.T.A.A) } \\
\text {-State Information Service } \\
\text { (SIS) } \\
\text { - The Egyptian Executive } \\
\text { chefs Association } \\
\text { - Cooking channels such } \\
\text { as CBC Sofra. } \\
\text { - Ministry of Tourism and } \\
\text { Antiquities. } \\
\text { - Matrouh Governorate. } \\
\text { - Ministry of agriculture. } \\
\text {-Ministry of environment } \\
\text { - Regional Authority for } \\
\text { the Promotion of } \\
\text { Tourism. } \\
\text {-Egyptian Tourism } \\
\text { Federation. } \\
\text { - Crafts and agricultural } \\
\text { co-operatives of siwa }\end{array}$ & $\begin{array}{l}\text { Branding local } \\
\text { cuisine with date } \\
\text { palm. } \\
\text { Promoting } \\
\text { creative } \\
\text { industries of } \\
\text { date palm. } \\
\text { reviving of Date } \\
\text { palm cultural } \\
\text { heritage. } \\
\text { Promoting } \\
\text { educational } \\
\text { tourism. } \\
\text { Re-positioning } \\
\text { and Branding } \\
\text { siwa as AHST }\end{array}$ \\
\hline
\end{tabular}




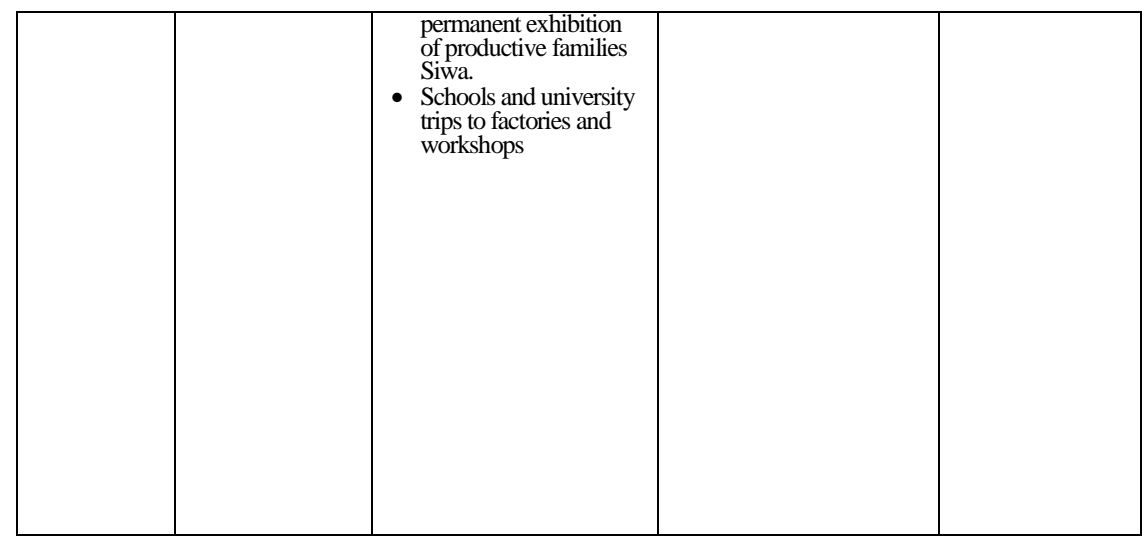

Source : The researchers

\section{The expected impacts}

\section{The economic impacts}

- Enhancing the entanglement of tourism and agriculture sectors by reducing imports and increasing the added value of date palm in both sectors.

- Increasing family income especially for women.

- job creation (local guide at farms, sellers of palm-made souvenirs).

- Food security

- Poverty alleviation

- Sustainability of date palm cultivation .

- fair in the distribution of income without monopolistic practices.

- Increasing hospitality facilities.

- enhancing rural development. 


\section{The socio/cultural impacts}

- Maintaining the unique identity of the destination of Siwa as (AHST) destination.

- $\quad$ ensuring authentic and rich tourist experience.

- enhancing traditional collective and individual knowledge systems of the indigenous farmers in Siwa.

\section{The environmental impacts}

- Encouraging sustainability of Siwa as one of (GIHAS). 
Potentials of Agricultural Heritage Systems

Tourism (AHST): A case study of date palm uses in gastronomy, Siwa Oasis - Egypt

Table(3):A suggested creative menu of date palm items Breakfast

Ajwa dates with eggs

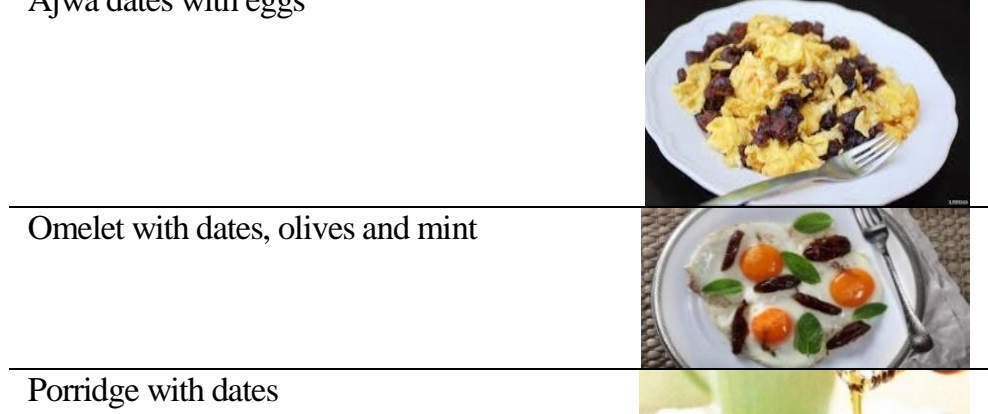

Porridge with dates

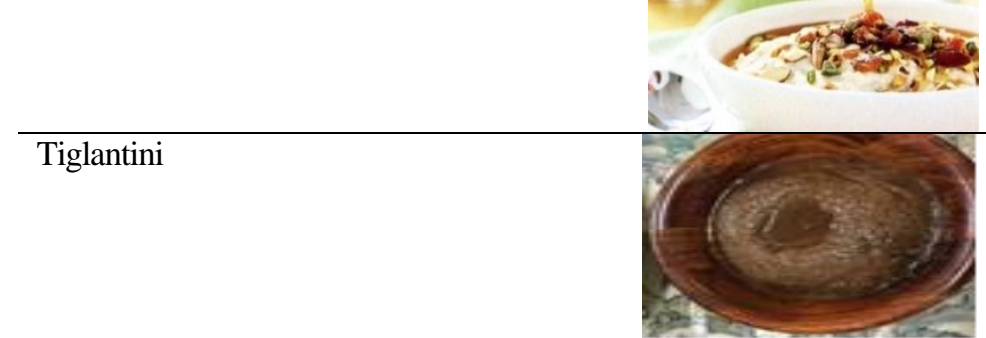

\begin{tabular}{ll}
\hline Appetizer \\
\hline Spring rolls with dates and almonds \\
\hline Kiri and date squares
\end{tabular}


Dates stuffed with cream cheese

Date Canapé (Nutella Banana Sandwich / Date Molasses \& Peanut Butter Sandwich

Grilled chicken wings (date molasses)

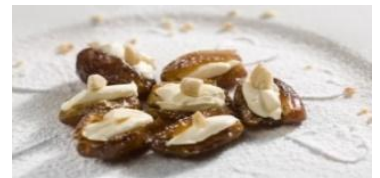

Green Beans with Pecans and Date Syrup

Herby cheesy date

Dates stuffed with white cheese and sprinkled with pistachios and paprika

Dates stuffed with roomy cheese and olives and wrapped with lamb tinsels

Dates stuffed with roumi cheese and olives and wrapped with zucchini tinsel
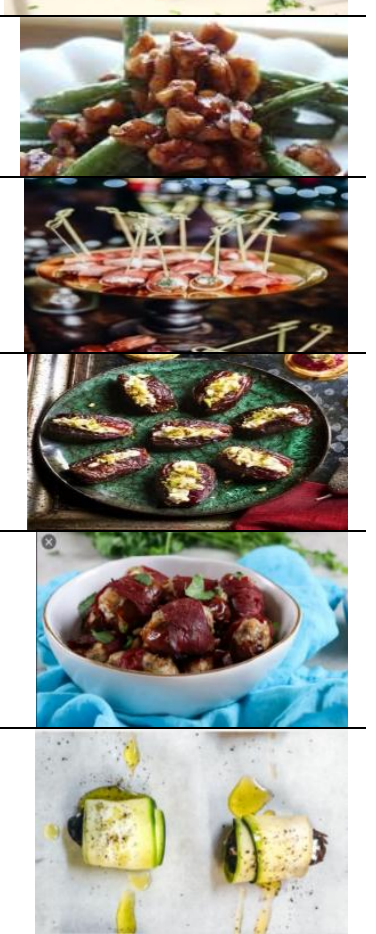
Potentials of Agricultural Heritage Systems

Tourism (AHST): A case study of date palm uses in gastronomy, Siwa Oasis - Egypt

cheese stuffed dates with pomegranate

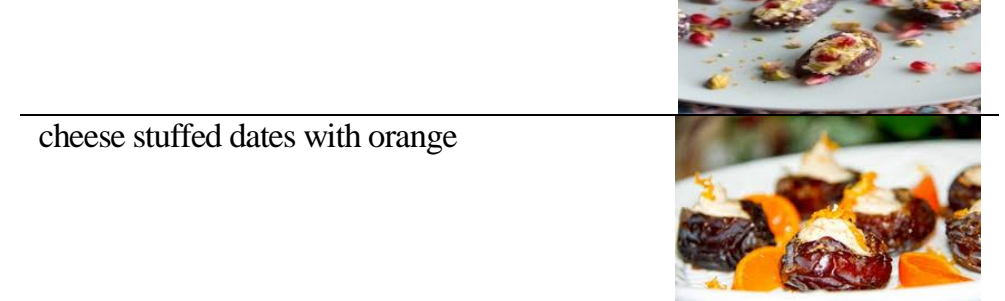

\begin{tabular}{ll}
\hline Soups \\
\hline Chicken, Red Dates and Ginger Soup \\
\hline Red Dates soup with Mint \\
\hline Date cream soup
\end{tabular}

Date soup

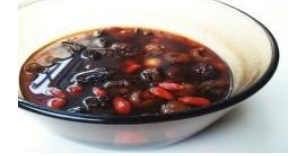




\begin{tabular}{|c|c|}
\hline 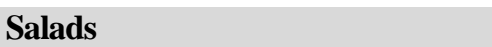 & Item \\
\hline Watercress and dates salad & \\
\hline Watercress salad with pomegranate & \\
\hline dates salad & \\
\hline Roquefort, pear and date salad & \\
\hline Quinoa salad with dates and oranges & \\
\hline Spinach, cheese and dates salad & \\
\hline Pumpkin salad and dates with cheese & \\
\hline
\end{tabular}


Potentials of Agricultural Heritage Systems

Tourism (AHST): A case study of date palm uses in gastronomy, Siwa Oasis - Egypt

Eggplant salad with tomatoes and dates on the Tunisian way

Dates orange salad with mint

Feta Olive salad

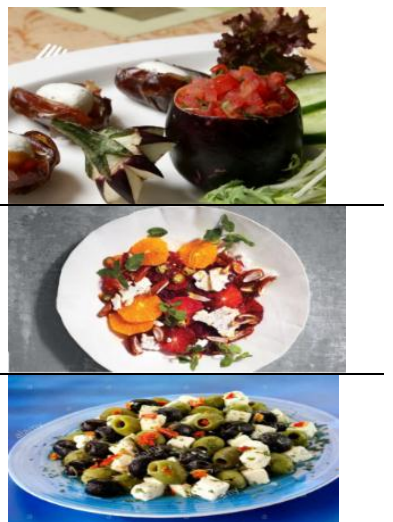

Marinated olive and Tomatoes salad

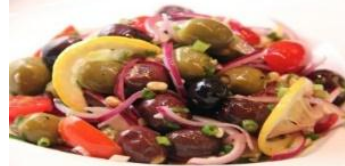

\section{Maine courses and side}

Item dishes

\begin{tabular}{lll}
\hline Freekeh with dates & \\
\hline béchamel Pasta with dates & $\begin{array}{l}\text { Baskets grilled steaks and dates on } \\
\text { basalt stone }\end{array}$ \\
\hline Moroccan lamb Tagin With Dates &
\end{tabular}




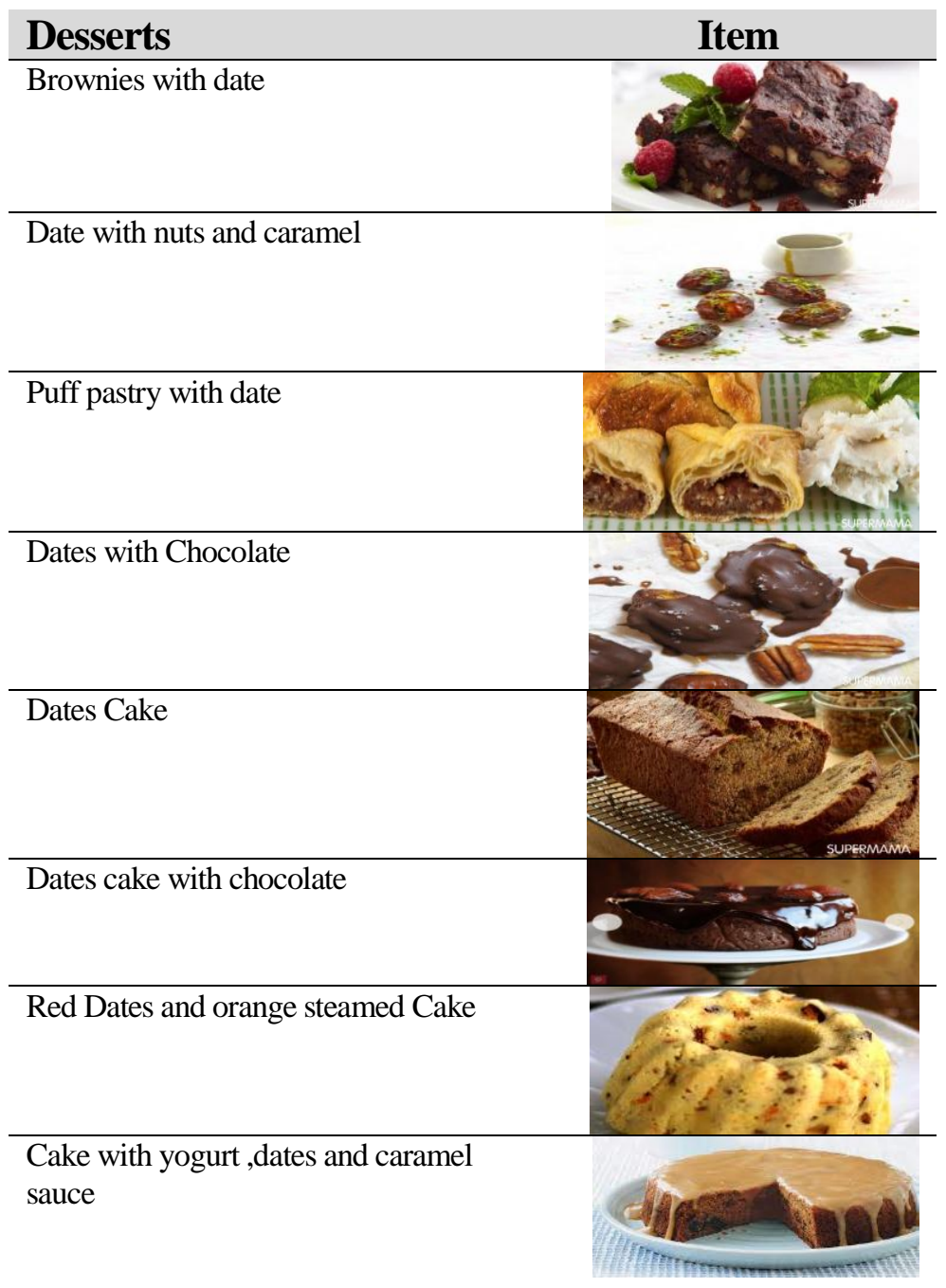


Potentials of Agricultural Heritage Systems

Tourism (AHST): A case study of date palm uses in gastronomy, Siwa Oasis - Egypt

Date cake with chocolate mousse

Date cake with coffee

Dates cheesecake

Date balls with nuts

Dates balls with chocolate sauce

Date balls with coconut

Date balls with sesame
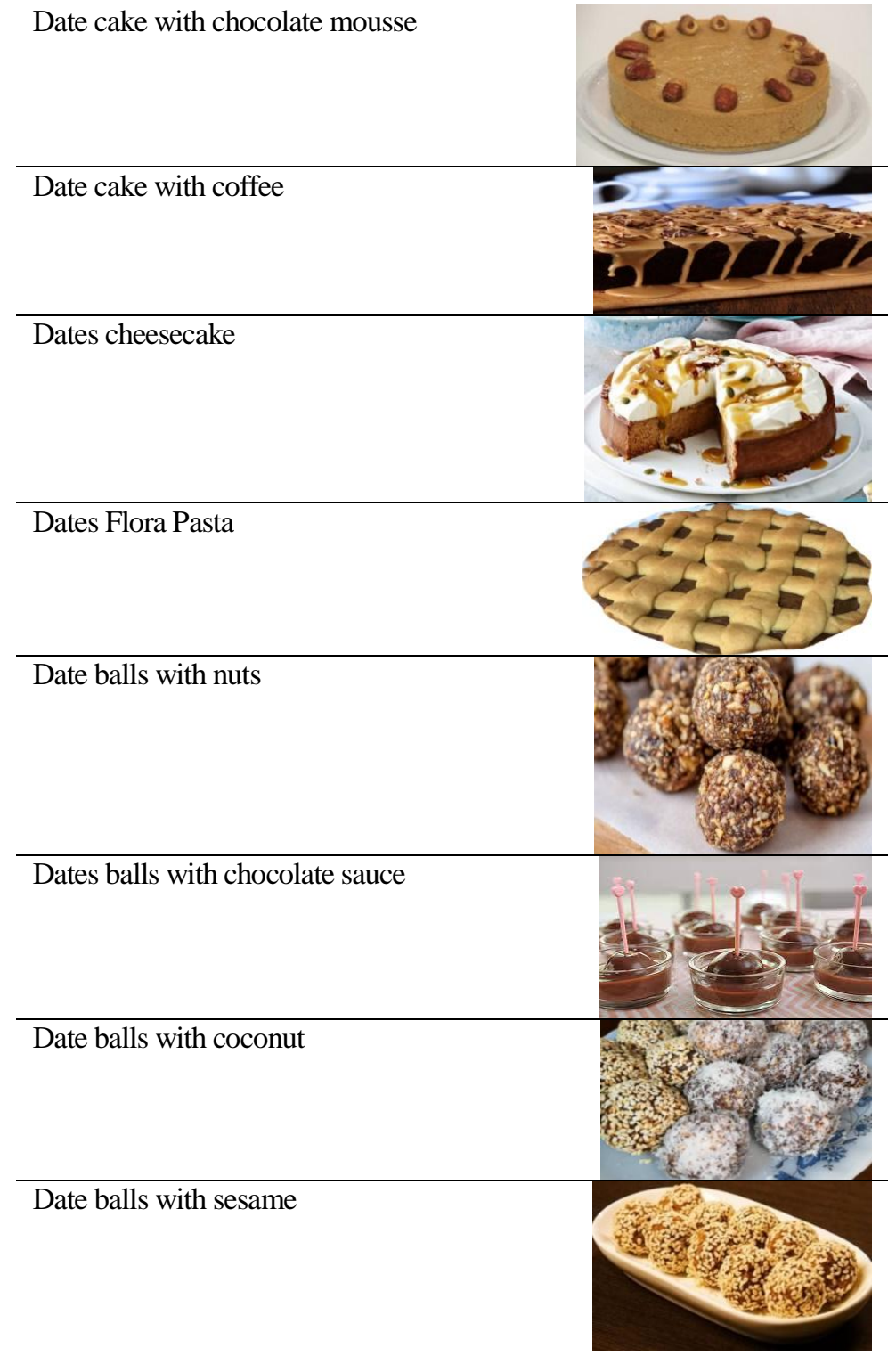
Date balls with pistachio

Biscuit Date Balls (Lotus Biscuit

Cookies with dates and oats

Dates and Coconut Cookies

Dates and chocolate cookies
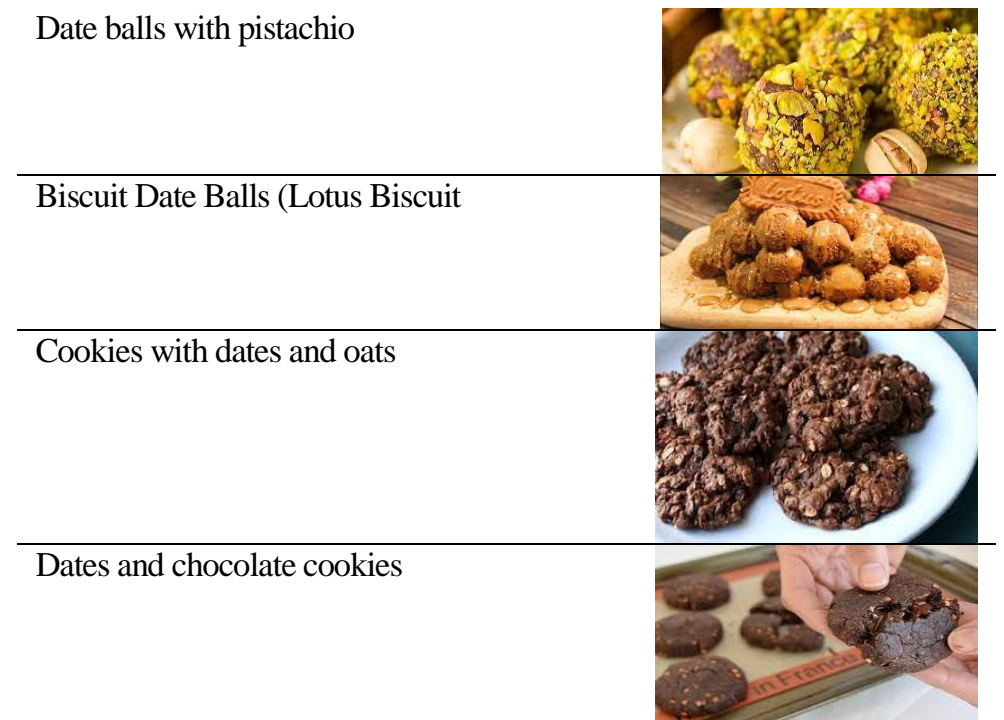

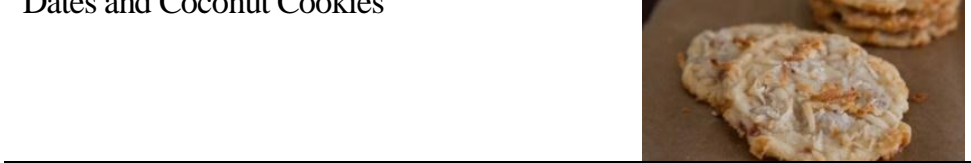

Date cupcakes

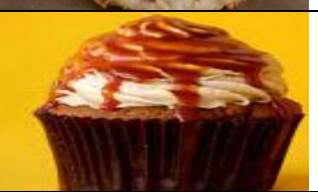

Dates and walnut cake

Dates millet cake 
Potentials of Agricultural Heritage Systems

Tourism (AHST): A case study of date palm uses in gastronomy, Siwa Oasis - Egypt

Dates cake with toffee

Date cake with cinnamon and apple

Date cake with walnuts and chocolate chips

Dates tart with caramel

Crepe with date molasses

Date pudding 


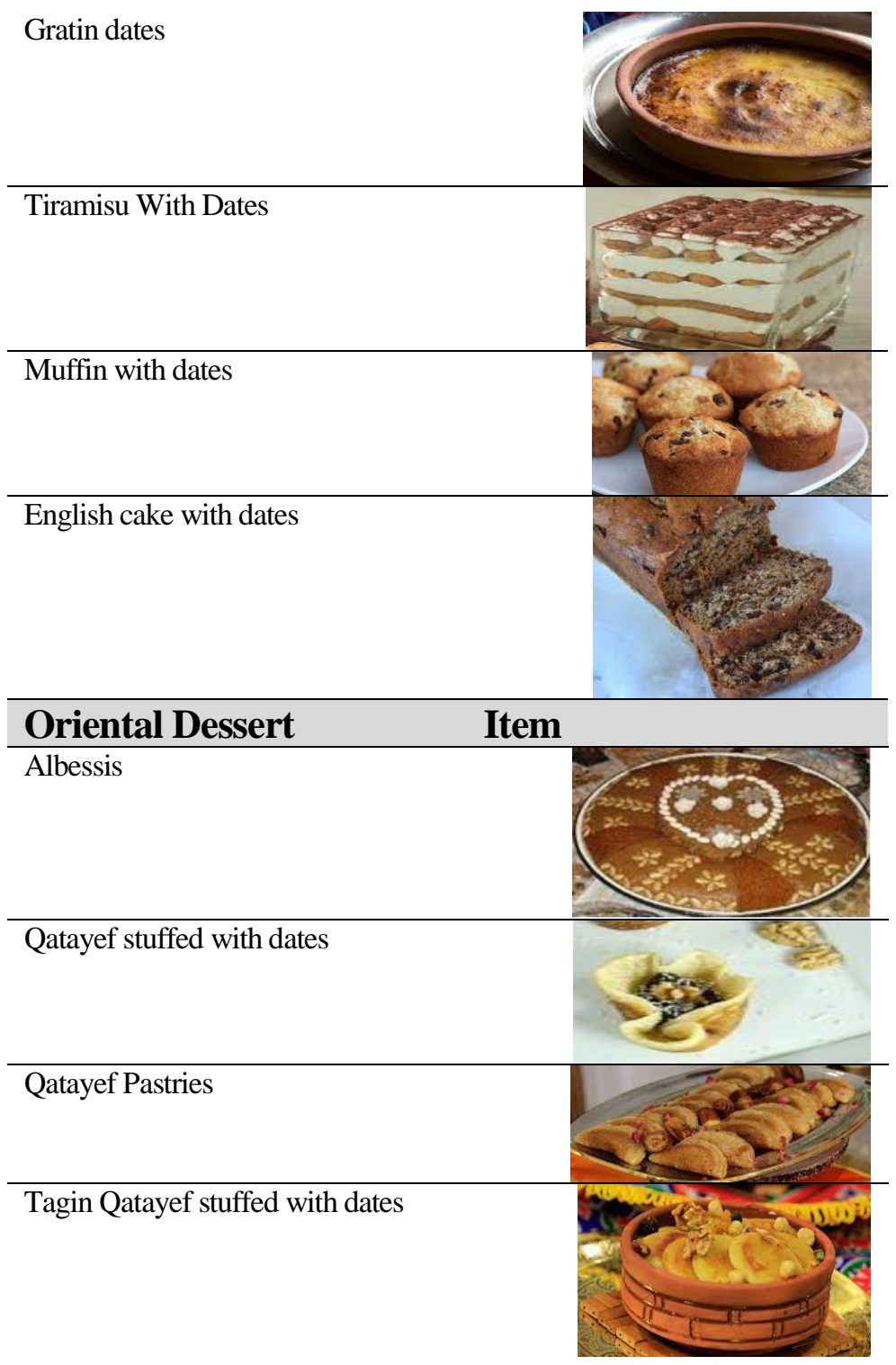


Potentials of Agricultural Heritage Systems

Tourism (AHST): A case study of date palm uses in gastronomy, Siwa Oasis - Egypt

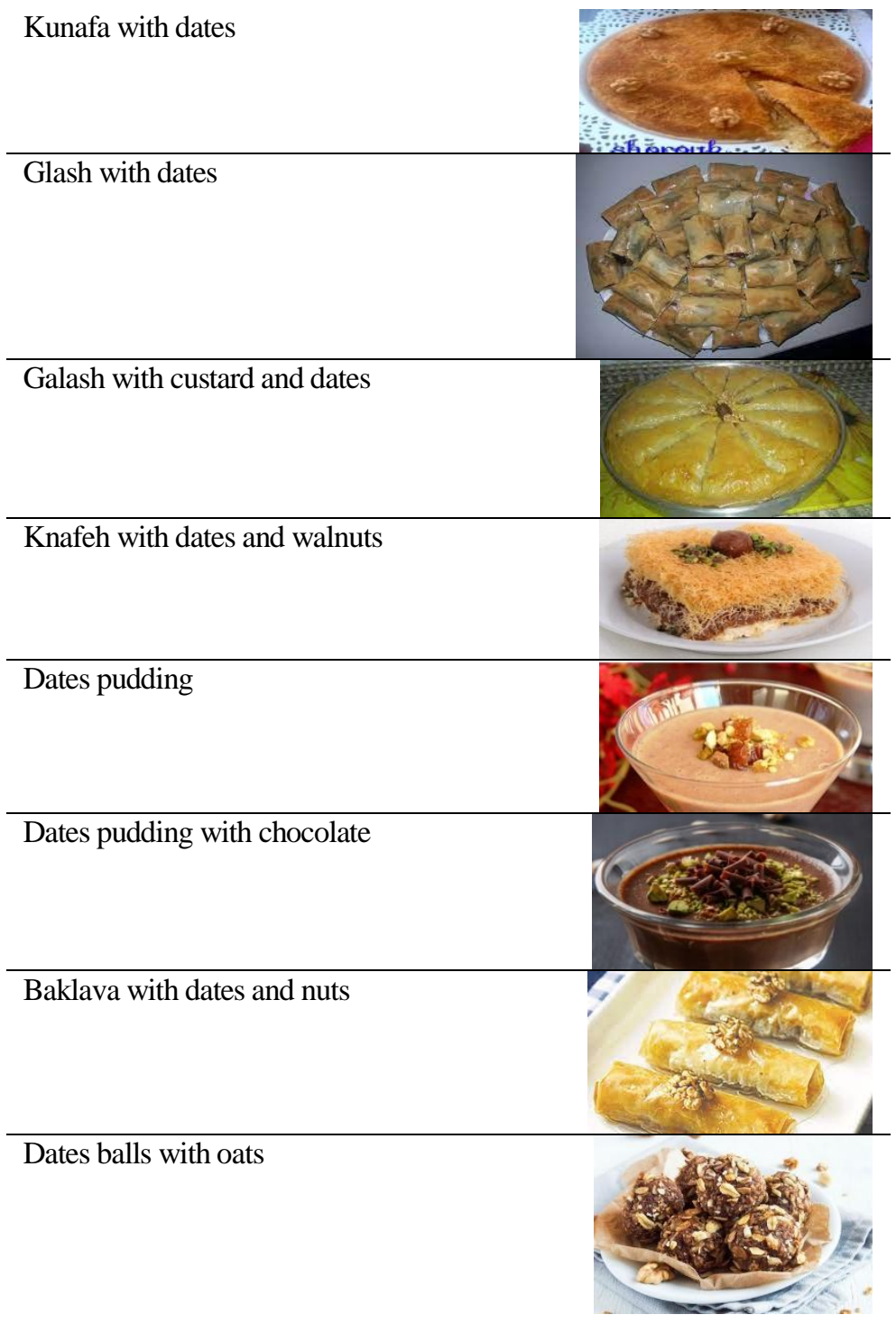




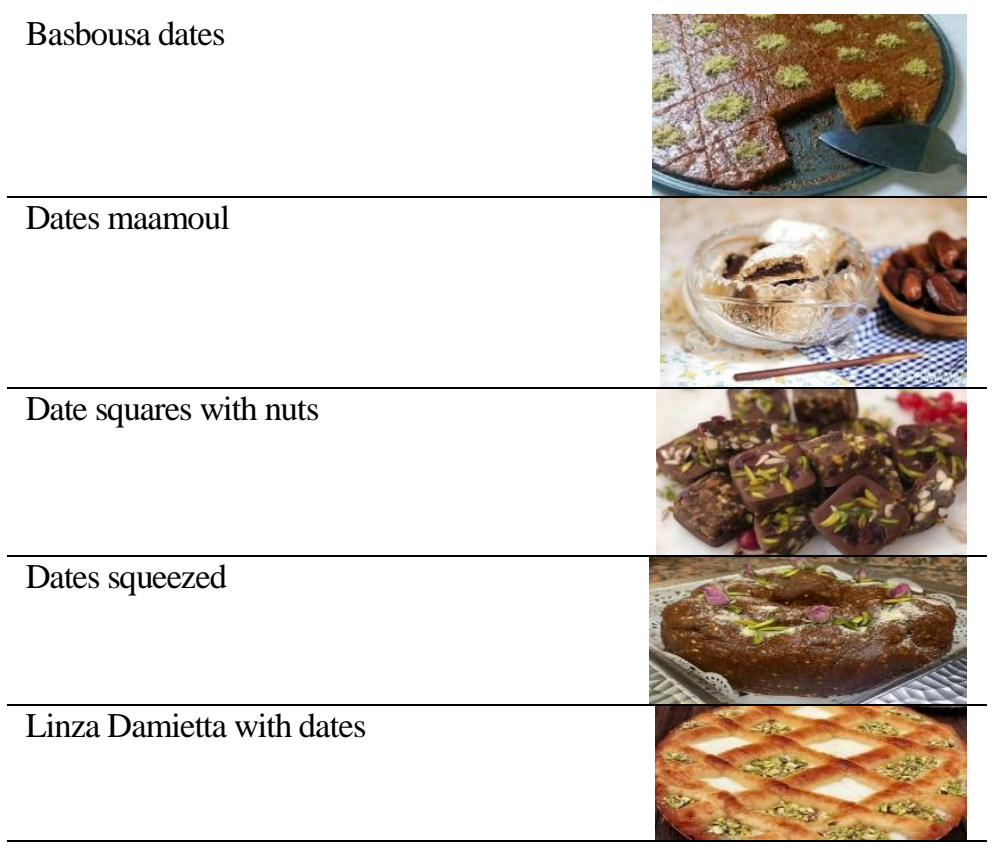

\begin{tabular}{ll}
\hline Oats with dates and milk & Item \\
\hline Bakery & \\
\hline Croissant with dates &
\end{tabular}


Potentials of Agricultural Heritage Systems

Tourism (AHST): A case study of date palm uses in gastronomy, Siwa Oasis - Egypt

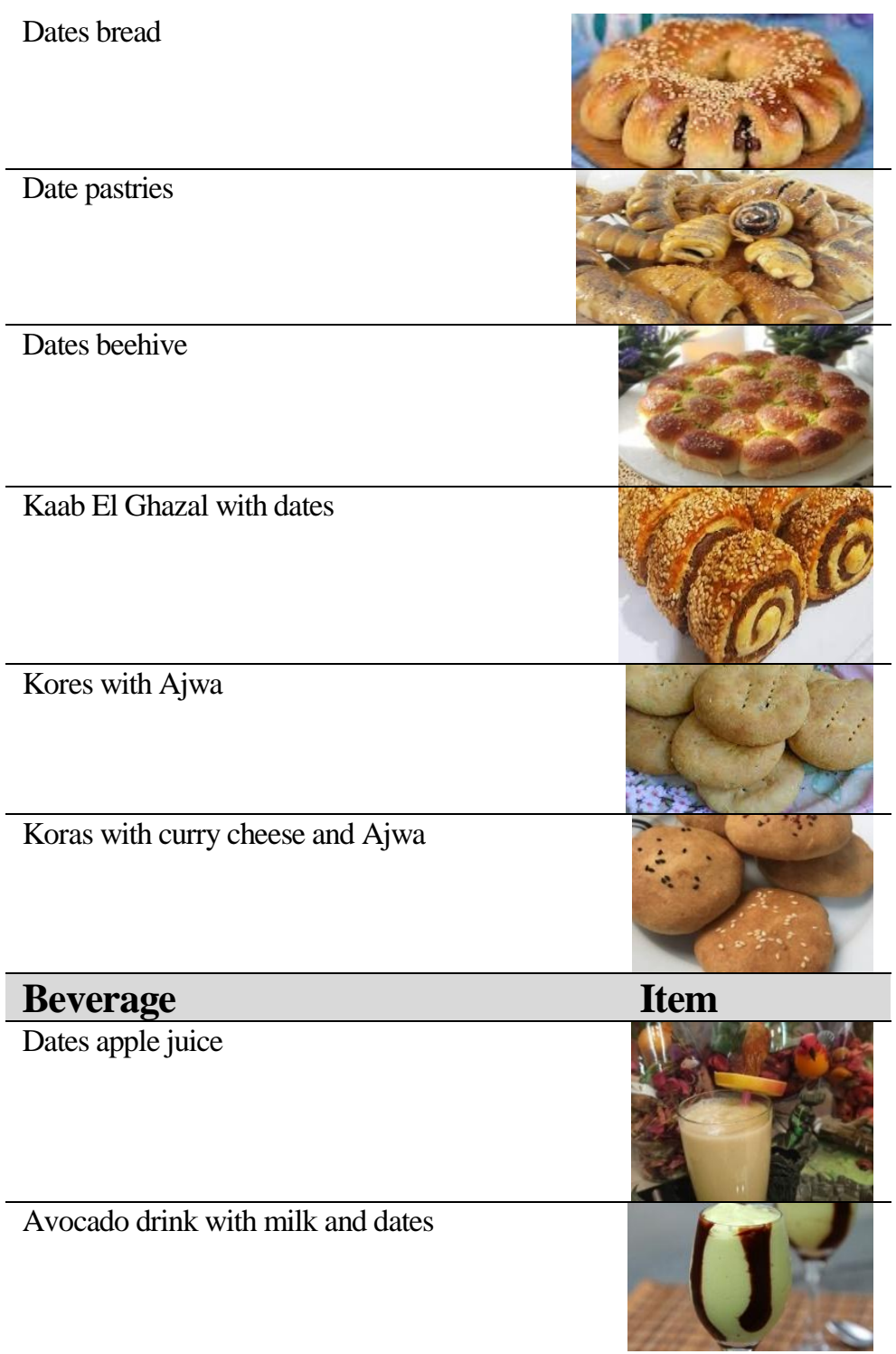


Milk juice with dates

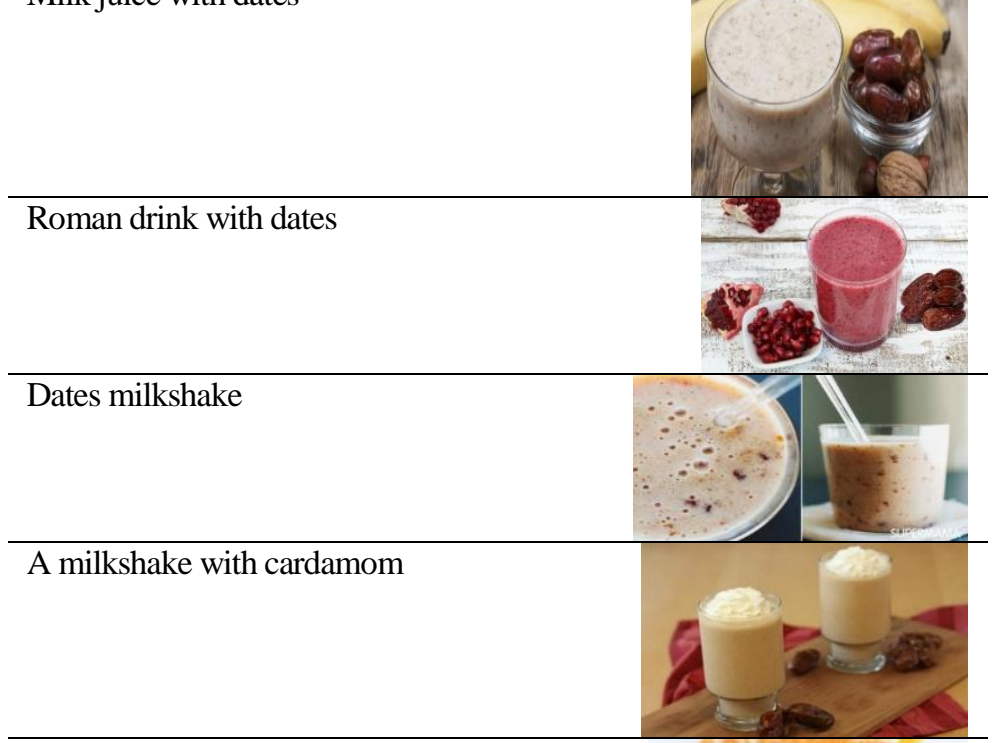

Dates and banana cocktail

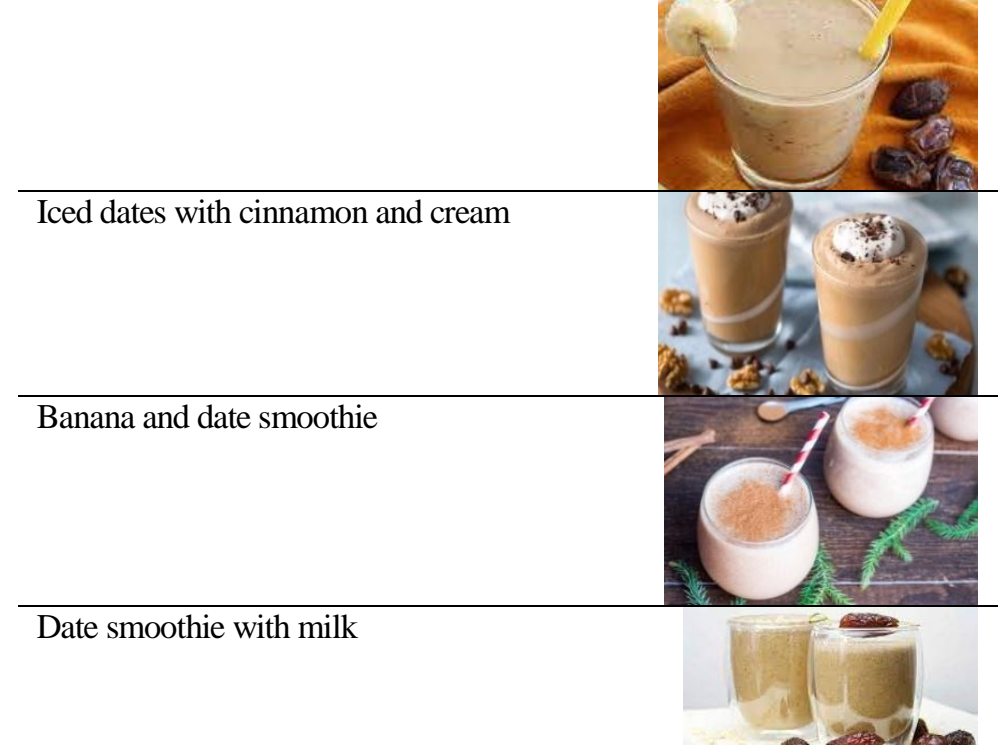


Potentials of Agricultural Heritage Systems

Tourism (AHST): A case study of date palm uses in gastronomy, Siwa Oasis - Egypt

Date smoothie with cinnamon

Milk with dates, nuts and cream

Chantilly

Dates seed coffee

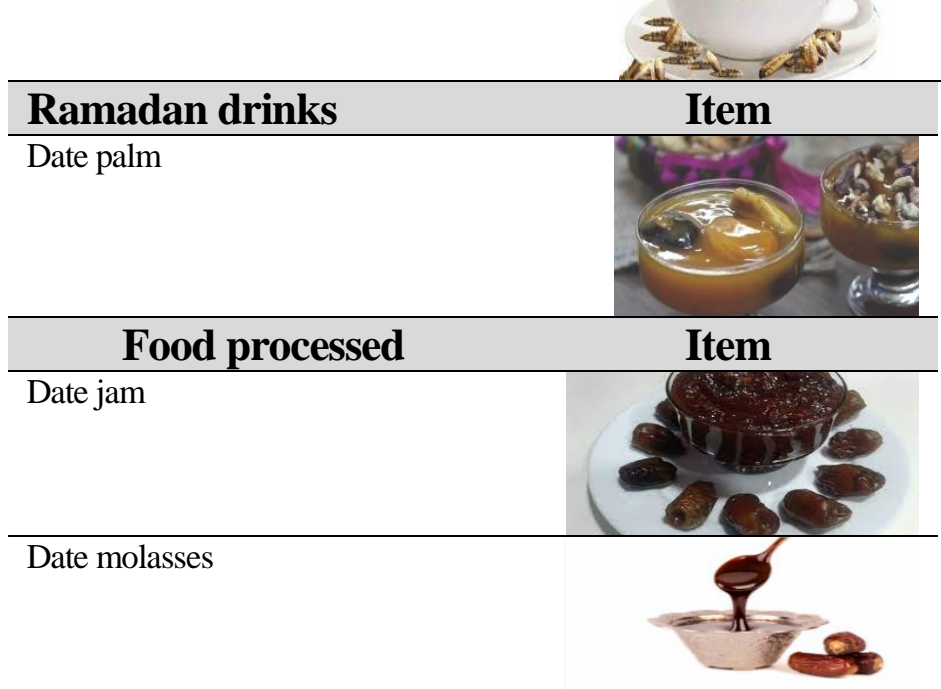

Tamarella (nutella with dates)(

Source: The researchers

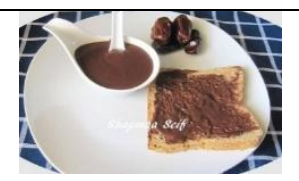

\section{The above menu was designed upon the following:}

- Reliance on dates as an alternative to nuts and sugar in some varieties. 
- Reliance on dates and their derivatives, such as date vinegar, date molasses, and date jam and in the menu items.

- $\quad$ Reliance on mint and lemon grass as a complete aromatic herb for most menu dishes and as a whole for most of the menu items. 
Potentials of Agricultural Heritage Systems

Tourism (AHST): A case study of date palm uses in gastronomy, Siwa Oasis - Egypt

\section{Conclusion and future researches}

In the frame work of promoting the Agricultural Heritage Systems Tourism (AHST) as a promising tourist pattern in order to boost the rural development; the current study developed a strategy for maximizing the date palm uses in cuisine, and other tourist activities. The study indicated that local community involvement is extremely important to achieve the sustainability of (GIAHS) through the development of agri- tourism. In spite of the limited current uses of date palm in, there can be future creative uses due to government initiatives for rural development in Siwa. Moreover, this will enrich tourist experience through using date palm in food menus as alternatives for sugar and nuts and derivatives such as date vinegar, date molasses and date jam. Also, relying on olive, mint and lemongrass as the complete aromatic herbs for most menu items. In other words, Siwa traditional food could be presented in innovative ways according to the modern gastronomy. In conclusion, it is important to emphasize that good tourism management practices in (GIHAS) require integrated strategies implemented by all the stakeholders such as restaurants, hotels, farms, travel agencies, the public and private sectors. Egyptian Authority for Tourism promotion should organize agri-package tours in Siwa. Culinary tourism campaigns are necessary to maintain the identity of date palm in the agricultural heritage of Siwa. Future researches should examine the role of the national and local government, local community in sustainable tourism development in Siwa. Other types of researches should emphasize on tourist motivations and satisfaction with each activity in siwa as an agricultural heritage system destination. 


\section{References}

Abd Elghani,M. (2012)Heritage and hospitality links in hotels in Siwa, Egypt: Towards the provision of authentic experiences, A thesis presented to the University of Waterloo in fulfillment of the thesis requirement for the degree of Doctor of Philosophy in Geography Waterloo, Ontario, Canada.

Abdel Rassoul,S.E. and Fathy,E.A. (2019)Assessment of Food Safety Practices in Siwa's Hotels, The Scientific Journal of the Faculty of Tourism and Hotels, The Second International Conference of the Faculty of Hotel Tourism, Matrouh University, entitled "The Balanced Development of Siwa Oasis on the World Tourism Map, A Future Vision for Sustainability" from March 26-28, 2019.

Abdul Ghafar,M.S.(2014) Desertification and its impact on agriculture production in Siwa Oasis,Middle East Journal of Agriculture Research, Vol. 3(2),pp. 155-166.

Abul Hawa,et.al., (2007) Sustainable tourism in Siwa:An integrated strategy for the Siwa protected area, http://www.eeaa.gov.eg/portals /0/eeaaReports/NCSCB/ Specific\%20Reports

/Sustainable\%20Tourism\%20in\%20Siwa.pdf, Accessed:Oct, 2020.

Altieri,M.A. and Koohafkan,P.(2003) Globally Important Ingenious Agricultural Heritage Systems (GIAHS): extent, significance, and implications for development, http://www.fao.org/3/ap021e/ap021e.pdf,Accessed:May,2020, Accessed:June,2020.

Amara,D.F(2010) Tourism as a tool of development: the case study of Siwa oasis -Egypt western desert, Conference: SUSTAINABLE TOURISM 2010,Volume: 139.

Ammirato,S. et.al.,(2020) Agritourism and Sustainability: What We Can Learn from a Systematic Literature Review, Sustainability, Vol.12,Issue 22,pp.1-18. 
Potentials of Agricultural Heritage Systems

Tourism (AHST): A case study of date palm uses in

gastronomy, Siwa Oasis - Egypt

Asham,M.K.(2019) Intangible cultural heritage as a tool for community empowerment: A case study of the date palm Festival in Siwa Oasis, Egypt, Ottoman Journal of Tourism\& Management Research,Vol.4,Issue,1,pp.361-377.

Chauhan, E.(2020) Challenges to community participation in heritage tourism development: case studies of shahjahanabad and nizamuddin basti in new delhi, india, Sustainable Tourism,Vol.48, PP.225-233.

Coelho,F.C,Coelho,E.M.and Egerer,M.(2018) Local food: benefits and failings due to modern agriculture, Scientia Agricola vol.75, n.1, pp.84-94.

Daugstad,K. Rønningen,K. and Skar,B. (2006) Agriculture as an upholder of cultural heritage? Conceptualizations and value judgements-A Norwegian perspective in international context Journal of Rural Studies Vol.22(1),pp.67-81.

EEAA, Welcome to Siwa: Discover nature, http://eeaa.gov.eg/ portals/0/eeaaReports/ protect/Leaflets/siwa-english.pdf, Accessed:Oct,2020.

Egyptian Tourism Authority, Siwa Oasis, http://egypt. travel/en /regions/western -desert/siwa-oasis, Accessed:Oct,2020.

EL Hadad, A. and Ibrahim, O.(2017) The potential of ecotourism in Siwa Oasis: opportunities and obstacles International Journal of Heritage Tourism and Hospitality, Vol. (11), No. (1/2) pp.1-16.

Elmusharaf,K.(2016) QUALITATIVE SAMPLING TECHNIQUES Training Course in Sexual and Reproductive Health Research Geneva 2016, https://www.gfmer.ch/SRH-Course-2012/researchmethodology/pdf/Qualitative-sampling-techniques-Elmusharaf2012.pdf,Accessed:June,2020.

El-sharabasy,S.F and Rizk,R.M (2019), Atlas of date palm in Egypt, http://www.fao.org/3/ca5205b/CA5205B.pdf, Accessed: Feb,2020. 
FAO (2016) FAO awards Siwa Oasis, the Globally Important Agricultural Heritage Systems (GIAHS) Certificate and signs the first project within Strategy to develop Date Sector in Egypt, http://www.fao.org/neareast/news/view/en/c/450 664/, Accessed: Feb,2021.

FAO (2016) Siwa Oasis Egypt, Proposal for designation as Globally Important Agricultural Heritage Site May 2016, http://www.fao.org/3/a-bp825e.pdf, Accessed: May,2020

FAO(2016) Siwa Oasis, Egypt,http://www.fao.org/giahs/ giahsaroundtheworld /designated -sites/near east-and-north-africa/siwa-oasis/en/, Accessed: Feb,2020.

FAO (2018) globally important agricultural heritage systems Combining agricultural biodiversity, resilient ecosystems, traditional farming practices and cultural identity, http://www.fao.org/3/i9187en/I9187EN.pdf, Accessed:Feb,2020.

FAO(2020 a) FAO teams up with UNWTO to boost sustainable rural tourism to help strengthen rural economies and conserve ecosystems http://www.fao.org/giahs/news/archives/newsin2020/en/?page=3\&ipp=4\&tx_dynalist_pi1\%5B par\%5D=YToxOntzOjE6IkwiO3M6MToiMCI 7fQ\%3D\%3D, Accessed:May,2021 
Potentials of Agricultural Heritage Systems

Tourism (AHST): A case study of date palm uses in gastronomy, Siwa Oasis - Egypt

$\mathrm{FAO}(2020 \mathrm{~b})$ The place of sustainable tourism in preserving for incredible agricultural sites, http://www.fao.org/faostories/article/en/c/1309636/, Accessed:Feb,2021.

FAO(2021) FAO - GIAHS Programme \& ICOMOS share experiences and lessons learned on how to identify and support world heritage, http://www.fao.org/giahs/news/newsletterdetail/ar/c/1411444/, Accessed:July,2021

FAO, Accenting the culture in agriculture, http://www.fao.org/3/bp151e/bp151e.pdf, Accessed:Feb,2021.

When GIAHS Programme meets with Slow Food Foundation, http://www.fao.org/giahs/giahs-contributions/slowfoodfoundation/ar/, June,2021.

Fuller, A.M. et.al., (2015) Globally Important Agricultural Heritage Systems

(GIAHS) of China: the challenge of complexity in research Ecosystem Health and Sustainability Volume 1(2),pp.1-10.

Globally Important Agricultural Heritage Systems (GIAHS) https://www.clintonfoundation.org/clinton-globalinitiative/commitments/globally-important-agricultural-heritagesystems-giahs, Accessed:April,2020.

Grigorova, Z.Shopova,I. and Timareva ,S.(2016) Rural food tourism, Balkan and Near Eastern Journal of Social Sciences, Vol.2,Issue, 1,pp.35-41.

Halawa,Y.A.(2016) Rapid Growth Dynamics In Sensitive Urban Ecosystems: The Case of Siwa Oasis A Thesis submitted in the Partial Fulfillment for the Requirement of the Degree of Master of Science in Integrated Urbanism and Sustainable Design, University of Stuttgart and Ain Shams university.

Harvey,E.(2012) agro and culinary tourism getting to the next leve,13 TH annual Caribbean Conference on Sustainable tourism development, Guyana-April 15-18,2012. 
Hasan, E.A. (2016) Water management challenges and opportunities in Siwa Oasis, Egypt, Fourth African Regional conference,Egypt,2016.

Khangarot,G. and Sahu,P.(2019) Agro-Tourism: A dimension of sustainable tourism development in Rajasthan, Journal of Indian Management,Vol.24,No.4,pp.21-26.

Koohafkan (2003)Important agricultural heritage systems important agricultural heritage systems https://satoyama initiative.org/wpcontent/uploads/2014/09/03_Parviz-Koohafkan.pdf, Accessed:June,2020.

Mekawy,M. A.(2017)Bilateral Relationship between Tourism and Date Palm Dar Al-Fajr for Publ. \& Dist.

Tian,M. et.al.,(2014) Progress and Prospects in Tourism Research on Agricultural Heritage Sites, Journal of Resources and Ecology Vol.5 No.4,pp. 381-389.

Moghazy,N.H. and Kaluarachchi,J.J.(2021) Sustainable Agriculture Development in the Western Desert of Egypt: A Case Study on Crop Production, Profit, and Uncertainty in the Siwa Region, Sustainability, vol. 12(16), p.p. 1-23..

Morales, L. et.al(2020) Value chain for agritourism products, $\underline{\text { Open }}$ Agriculture 5(1),pp.768-777.

Naidoo,P. and Pearce,p.(2018)"Enclave tourism versus agritourism: the economic debate,Current issues in Tourism, Vol.21, Issue,17,pp.19461965.

Nofal,E.(2011)Towards management and preservation of Egyptian cultural landscape sites-Case study:Siwa Oasis 5th International Congress "Science and Technology for the Safeguard of Cultural Heritage in the Mediterranean Basin” 22nd - 25th November 2011, Istanbul, Turkey. 
Potentials of Agricultural Heritage Systems

Tourism (AHST): A case study of date palm uses in gastronomy, Siwa Oasis - Egypt

Palinkas, L.A. et.al(2013) Purposeful Sampling for Qualitative Data Collection and Analysis in Mixed Method Implementation Research, Adm Policy Ment Health, 42(5), pp. 533-544.

Patton,M.Q.(2015)" Sampling, Qualitative (Purposeful)

https://onlinelibrary.wiley. com/doi/full/10.1002/9781405165518.wbeoss012.

pub2, Accessed:Oct,2020.

Rinaldi,C.(2017) Food and Gastronomy for Sustainable Place

Development: A Multidisciplinary Analysis of Different Theoretical Approaches,sustainability,9(10),pp.1-25.

Saleh,R.A(2017)_The Governmental Efforts in Emphasising Identity through Art Projects"Siwa Oasis studios as a case study The Academic Research Community Publication 1(1),pp.1-16.

Samy,A.(2014)"Sustainable Agriculture Development, Siwa

Oasis,Western Desert, Egypt, http://www.oss-online.org/mena

delp/phocadownload/success_stories/Siwa \%20Succcess \%20Story.pdf, Accessed:Feb,2020.

Sidali, K, L. and Spiller, A, Birgit,S.(2011) Food, Agri-Culture and Tourism Linking Local Gastronomy and Rural Tourism:

Interdisciplinary

Perspectives,https://www.springer.com/gp/book/9783642113604,

Acessed,Feb,2020.

Siwa Oasis, laboasis.org, Accessed:June,2020.

Siwa project (2010), http://www.siwa-oasis.it/shali.html,

Accessed:Oct,2020.

Sorcaru,I.A (2019) Gastronomy Tourism-A Sustainable Alternative for

Local Economic Development," Economics and Applied Informatics,

"Dunarea de Jos" University of Galati, Faculty of Economics and

Business Administration, issue 1, pp. 103-110.

Sormaz,U. et.al.,(2016) Gastronomy in Tourism, Procedia Economics and Finance Vol.39,pp. 725 - 730.

Srivastava,S.(2016) Agritourism as a Strategy for the Development of Rural Areas 
Case Study of Dungrajya Village, Southeast Rajasthan, India Journal of Medical and Dental Science Research, Vol. 3,Issue 6, pp: 35-39.

Su,M.M. et.al.,(2018) A Community Livelihood Approach to Agricultural Heritage System Conservation and Tourism Development: Xuanhua Grape Garden Urban Agricultural Heritage Site, Hebei Province of China, sustainability,10(2),pp.1-14.

Sullins, M. Moxon,D. and McFadden,D.T.(2010) Developing Effective Marketing Strategies for Agritourism: Targeting Visitor Segments, Journal of Agribusiness ,Vol.(28),Issue(2),pp.111-130.

Sun,Y. et.al.,(2011)Tourism Potential of Agricultural Heritage Systems, AnInternational Journal of Tourism Space, Place and Environment,pp.112-128.

Sun,Y.H. et.al.,(2013) Conserving Agricultural Heritage Systems through Tourism: Exploration of Two Mountainous Communities in China, Journal of Mountain Science, Vol.10,issue 6,pp.962-975

https://ouik.unu.edu/en/events/3608, Accessed:April,2020.

Testa,R. et.al(2019) Culinary Tourism Experiences in Agri-Tourism Destinations and Sustainable Consumption-Understanding Italian Tourists' Motivations, Vol. 11 No. 17, p. 4588-4605.

Tian, M. et.al.,(2016)Agricultural Heritage Systems Tourism: Definition, characteristics and development framework Journal of Mountain Science, Vol.13,issue 3,pp.440-454.

\section{TOMPKINS COUNTY AGRICULINARY TOURISM}

IMPLEMENTATION

PLAN2020,https://tompkinscountyny.gov/files2/tourism/Agriculinary \%20Tourism\%20Implementation\%20Plan\%20\%209.16.pdf,Accessed:June,2021.

UNDP (2018)Tourism and the sustainable development goals journey to 2030,http://www.undp.org,accessed: Feb,2021.

UNESCO (2019), Date palm, knowledge, skills, traditions and practices, https://ich.unesco.org/ar/RL/-01509, Accessed: Feb,2020.

United Nations University (2020)Building back better with globally important agricultural heritage systems (giahs) from the covid-19 pandemic, https://ouik.unu.edu/en/events/3608, accessed: jan,2021. 
Potentials of Agricultural Heritage Systems

Tourism (AHST): A case study of date palm uses in gastronomy, Siwa Oasis - Egypt

United Nations (U.N),Globally Important Agricultural Heritage Systems (GIAHS)

https://sustainabledevelopment.un.org/partnership/?p=2309, Accessed:April,2020.

UNWTO (2017)3rd UNWTO world forum on gastronomy tourism, https://www.unwto. org/archive/global/event/3rd-unwto-world-forumgastronomy-tourism, accessed: May,2020.

UNWTO (2018) tourism and the sustainable development goals journey to 2030 ,

https://www.unwto.org/global/publication/tourism -and-sustainable-development-goals-journey2030.

UNWTO (2020)a UNWTO and FAO to work together on developing tourism for rural development, https://www.unwto.org/news/unwto-and-fao-towork-together-on-developing-tourism-for-ruraldevelopment, Accessed: Feb,2020.

UNWTO (2020) b Tourism and Rural Development, https://www.unwto.org/ar/world-tourism-day-2020, Accessed:Sep,2020

UNWTO (2021) 2021 TOURISM AND RURAL DEVELOPMENT (MASTERS) https://www.unwto.org/students-leagueplatform/challenges/2021-tourism-and-rural-development-mastersglobal/38/, Accessed:Feb,2020. 
Vafadari,K.(2013)Exploring Tourism Potential of Agricultural Heritage Systems A: Case Study of the Kunisaki Peninsula, Oita Prefecture, Japan, Issues in Social Science,

Vol.1,Issue,1,http://www.macrothink.org/journal/i ndex.php/iss/article/view/4465.

Vafadari,K. (2014) Sustainable Tourism in GIAHS landscapes Case Studies from Asiav http://www.fao.org/fileadmin/templates/giahs/Pres entations/april2014sc/04/TourismGIAHSrome_20 14.pdf, Accessed:Feb,2020.

Vafadari,K.(2014)Tourism Applications of Globally Important Agricultural Heritage Systems (GIAHS) in Japan, International Journal of Ecology and Conservation,Vol.(10), Issue,(1), https://www.researchgate.net/publication/ 287562509Tourism_Applications_of_Globally_Important_Agricultur al_Heritage_Systems_GIAHSn_Japan, Accessed:Jan,2021.

Valdivia,C. and Barbieri,C. (2014)"Agri-tourism as a sustainable adaptation strategy to climate change in the Andean Altiplano, Tourism Management Perspectives,

What is Natural Heritage Tourism, https://www.idaholandcan.org/article/What-is-Natural-HeritageTourism/61, Acceseed,Feb,2021.

World Agricultural Heritage Foundation, Agricultural Heritage Systems and Sites feature distinctive characteristics of great importance and benefits to local, national, and global economy, https://worldagriculturalheritage.org, Accessed: pril,2020.

World Agricultural Heritage Foundation, Combining traditional wisdom and science, safeguarding the legacy of the past for the future, worldagriculturalheritage.org, Accessed: Jan,2021. 
Potentials of Agricultural Heritage Systems

Tourism (AHST): A case study of date palm uses in gastronomy, Siwa Oasis - Egypt

Yotsumoto,Y. and Vafadari, K(2020)Comparing cultural world heritage sites and globally important agricultural heritage systems and their potential for tourism,Journal of Heritage tourism, Vol.16,Issue,1.pp.43-61. 
إمكانيات سياحة نظم التراث الزراعي : دراسة حالة لاستخدامات

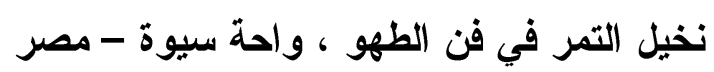

ملخص الهدف الرئيس من الار اسة الحالية هو تقديم إستر اتيجية لنمط سياحة أنظمة التراث الزر اعي • تهدف الإستر اتيجية إلى الحفاظ على نظام التراث الزراعي المستدام بسيوة من خلال استخدامات نخيل التمر في السياحة و الضيافة. تدمج الإستر اتيجية العلاقة الثلاثية بين المطبخ والمنتج و الإقليم. استخدمت الدراسة الحالية مقابلة شبه منظمة من أجل الحصول على أدق النتائج من خلال عينتين. الأولي العينة القصدية (العدية) و الثانية العينة الملائمة. أثـارت الدراسة إلى أن سباحة أنظمة التراث

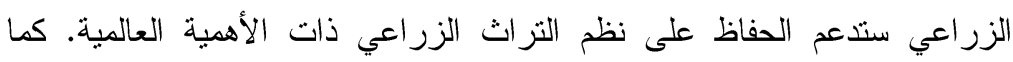
أشارت النتائج إلى أن هذا النمط من السياحة سيعزز معيشة المجتمع المحلي في سيوة وكذلك معظم أهداف التتمية المستدامة ـ كما أظهرت النتائج أن استخدامات

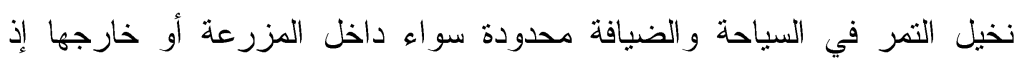
تستخدم فقط للمشروبات و الحلويات ، و لا يوجد في المز ارع مر افق كافية لاستقبال

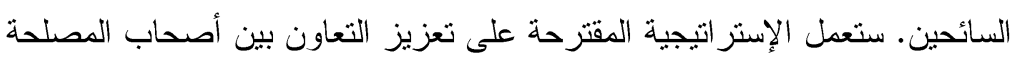

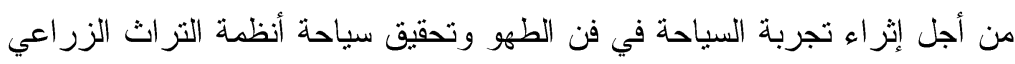
من خلال استخدامات نخيل التمر في عناصر قائمة الطعام وفي أنشطة السياحة

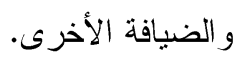
الكمات الدالة : نظم التراث الزراعي ذات الأهمية العالمية (GIAHS)، سياحة نظم التراث الزر اعي (AHST) ، استخدامات نخيل التمر ، فن الطهو ، سيوة 
Potentials of Agricultural Heritage Systems

Tourism (AHST): A case study of date palm uses in gastronomy, Siwa Oasis - Egypt

\section{Appendix}
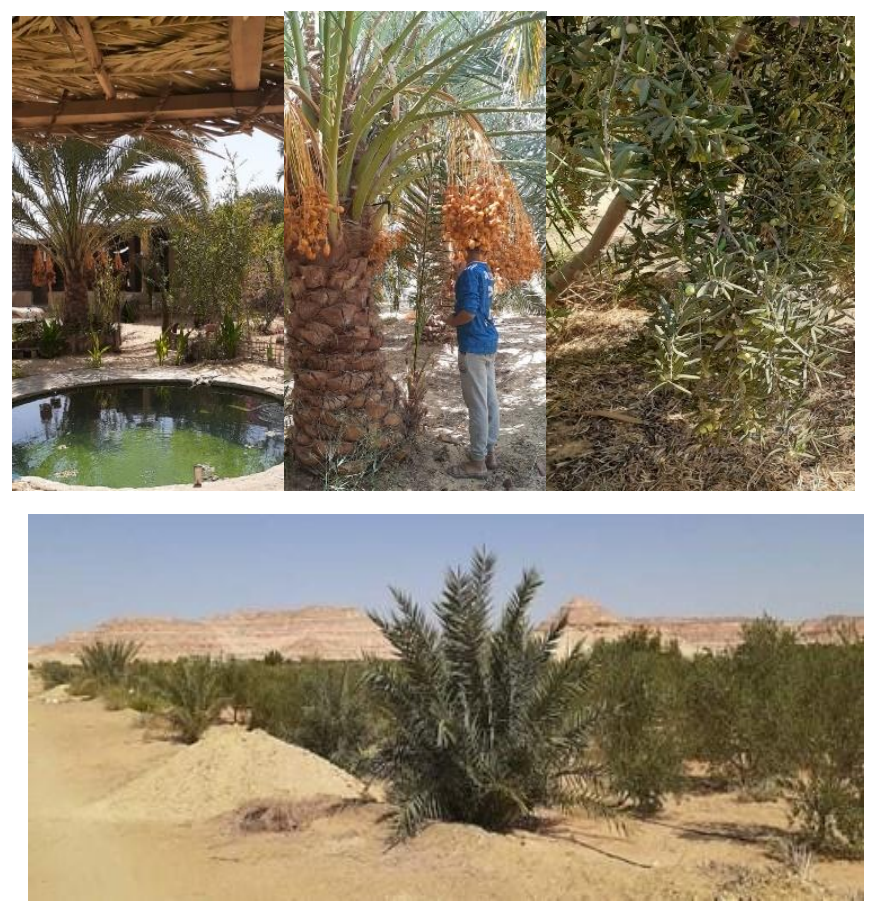

Fig. (1) Palm date and olive

Source: The researchers 


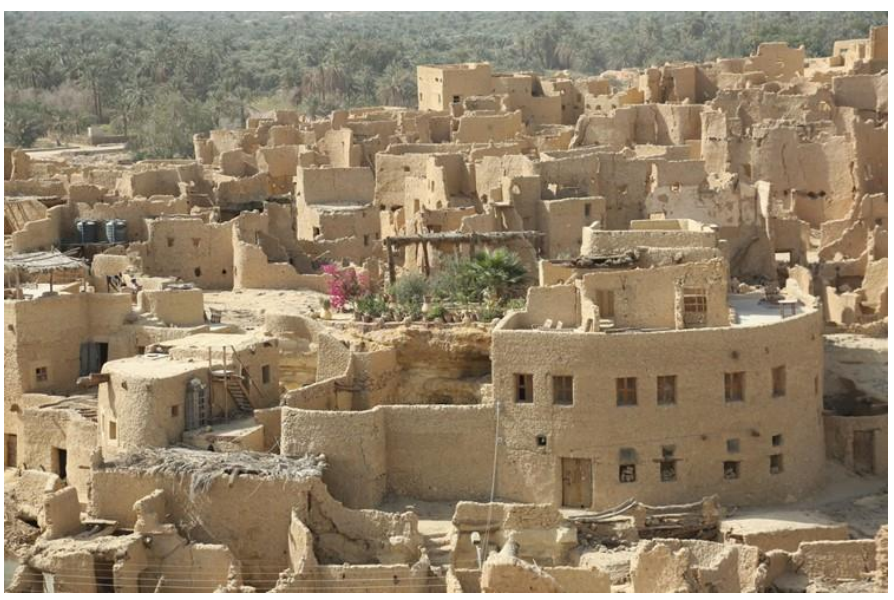

Fig. (2) Mud-salt brick architecture

Source: FAO 
Potentials of Agricultural Heritage Systems

Tourism (AHST): A case study of date palm uses in gastronomy, Siwa Oasis - Egypt

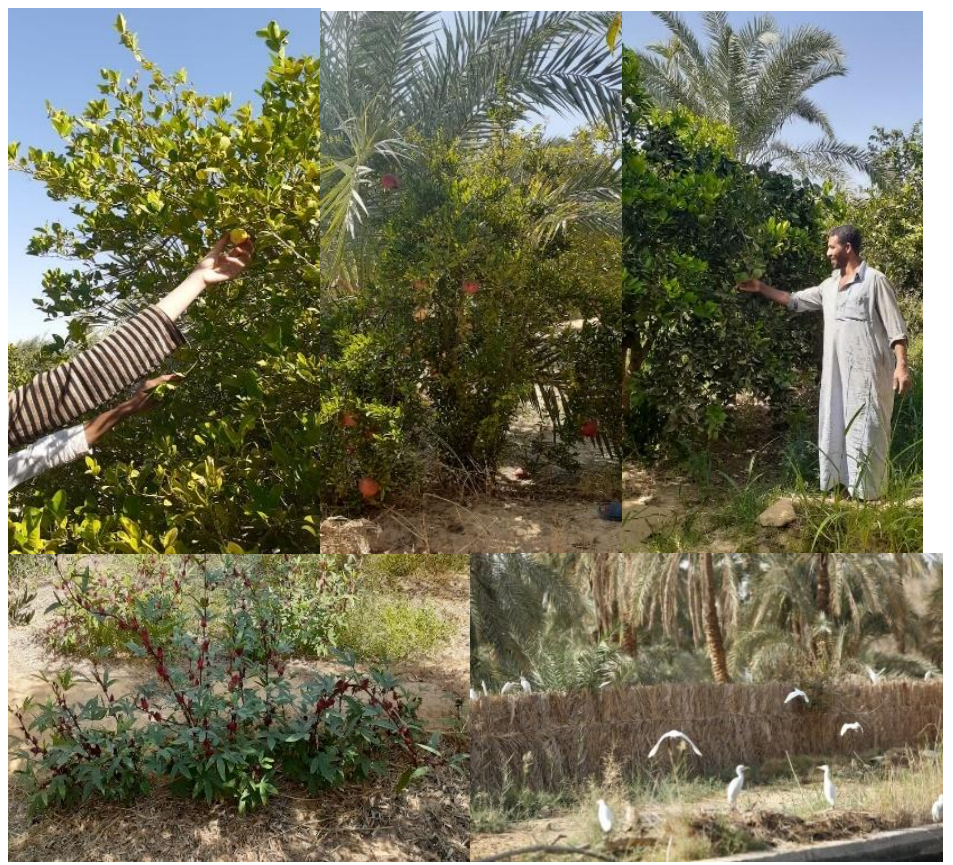

Fig. (3) Biodiversity in Siwa Source: The researchers and FAO 


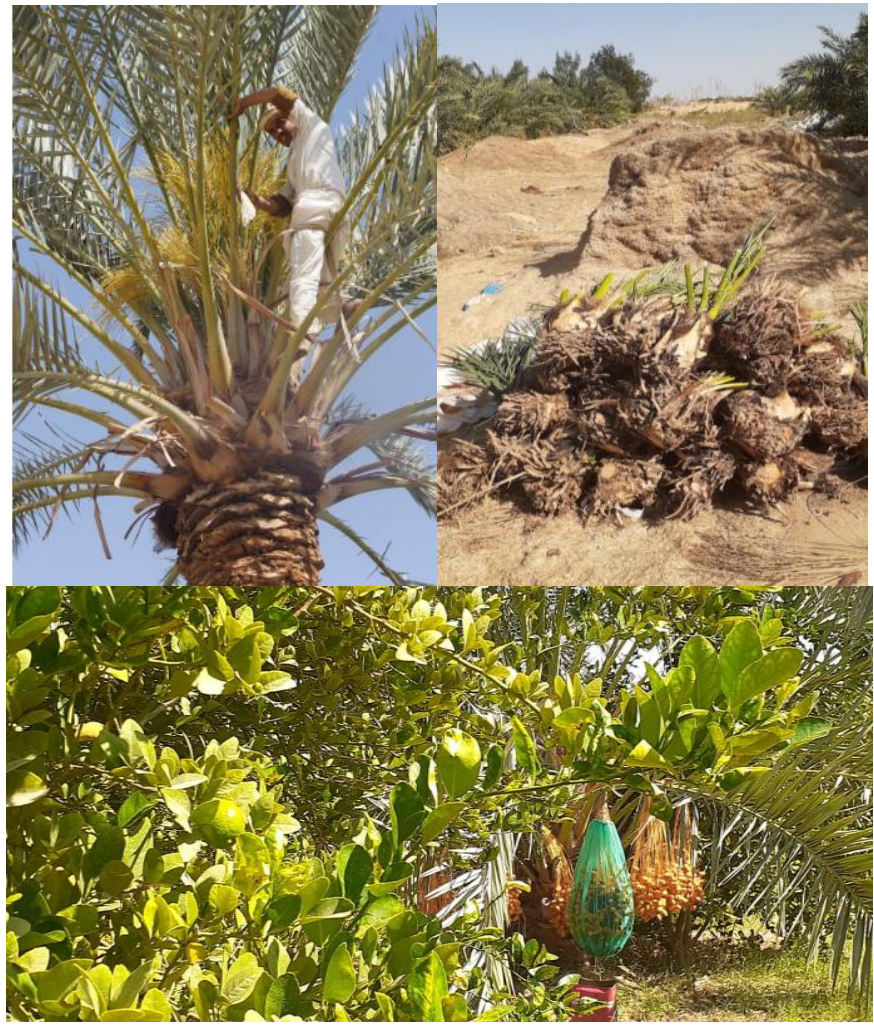

Fig. (4) Agricultural knowledge system Source: The researchers and FAO

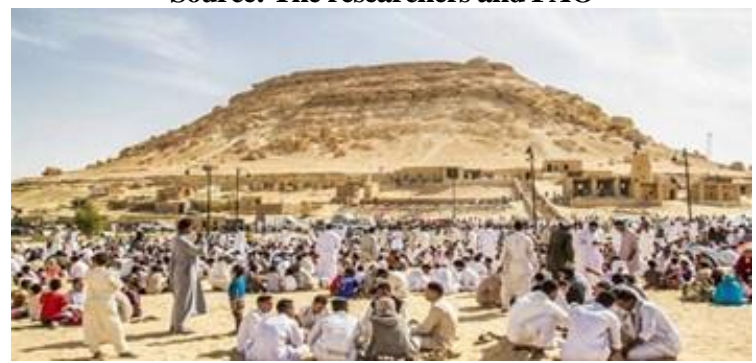

Fig. (5) Al-Seiaha festival Source: youm7.com 
Potentials of Agricultural Heritage Systems

Tourism (AHST): A case study of date palm uses in gastronomy, Siwa Oasis - Egypt
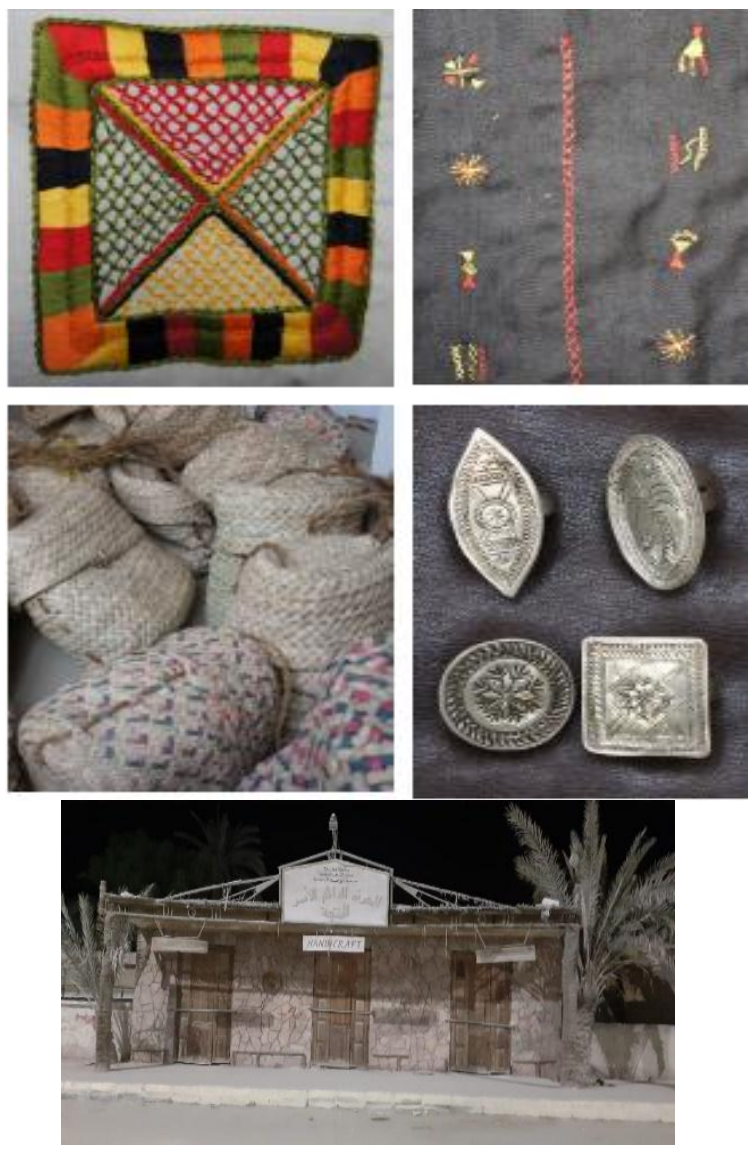

Fig. (6) handicrafts and creative industries Source: The researchers and FAO 


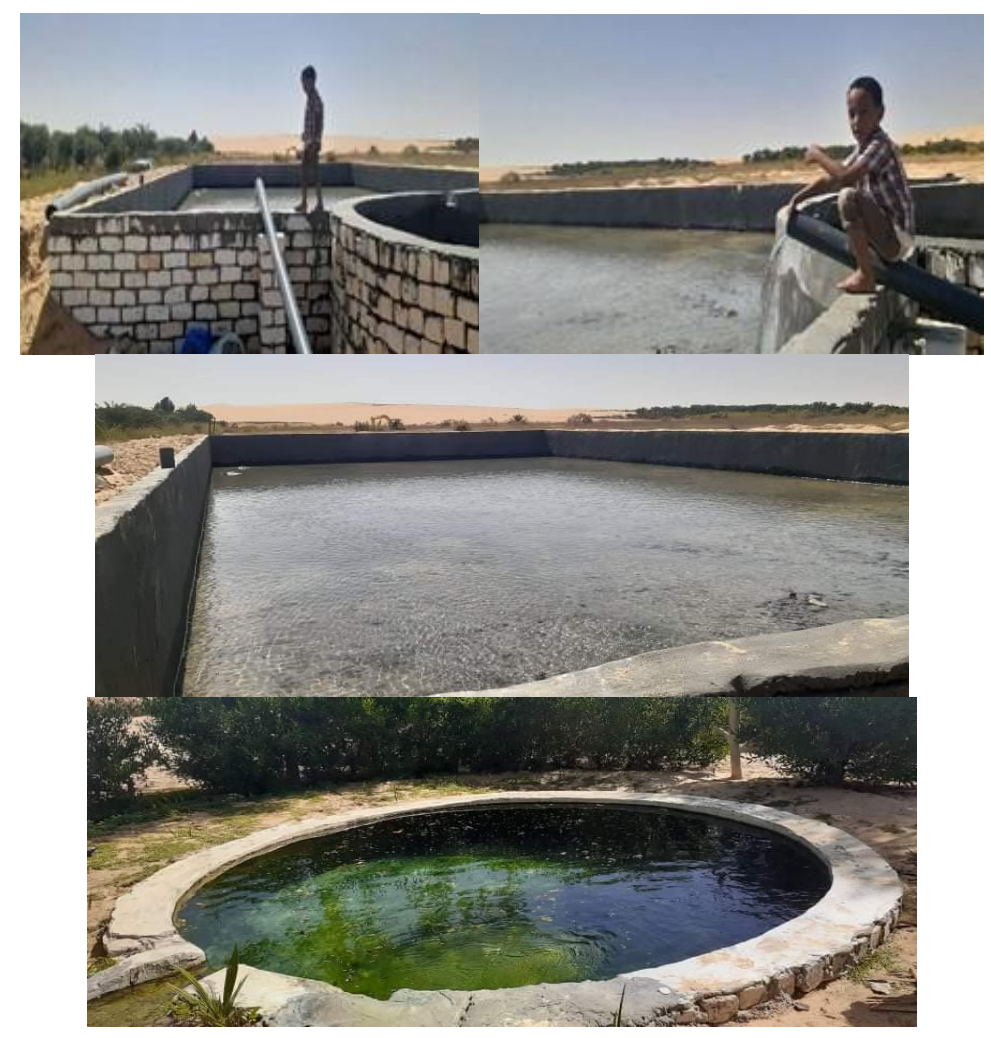

Fig. (7) Irrigation methods

Source: The researchers 
Potentials of Agricultural Heritage Systems

Tourism (AHST): A case study of date palm uses in gastronomy, Siwa Oasis - Egypt
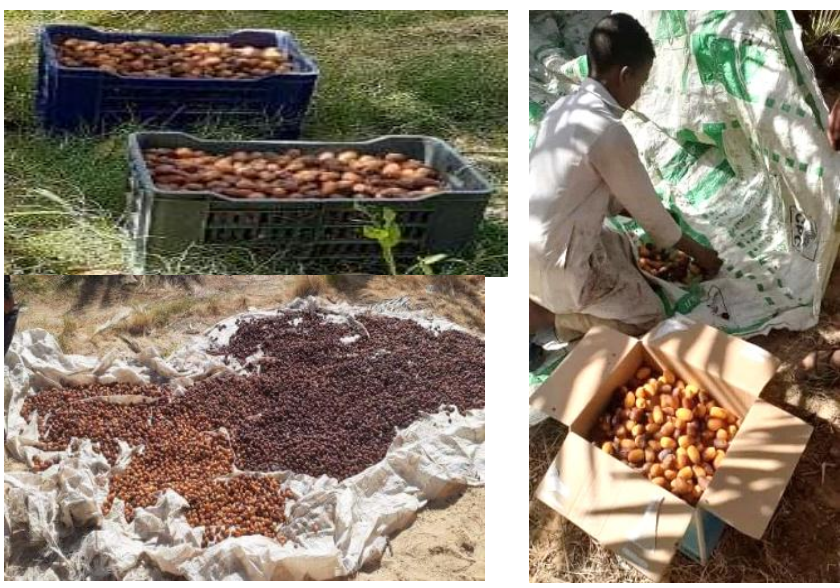

Fig. (8) Harvest season

Source: The researchers 


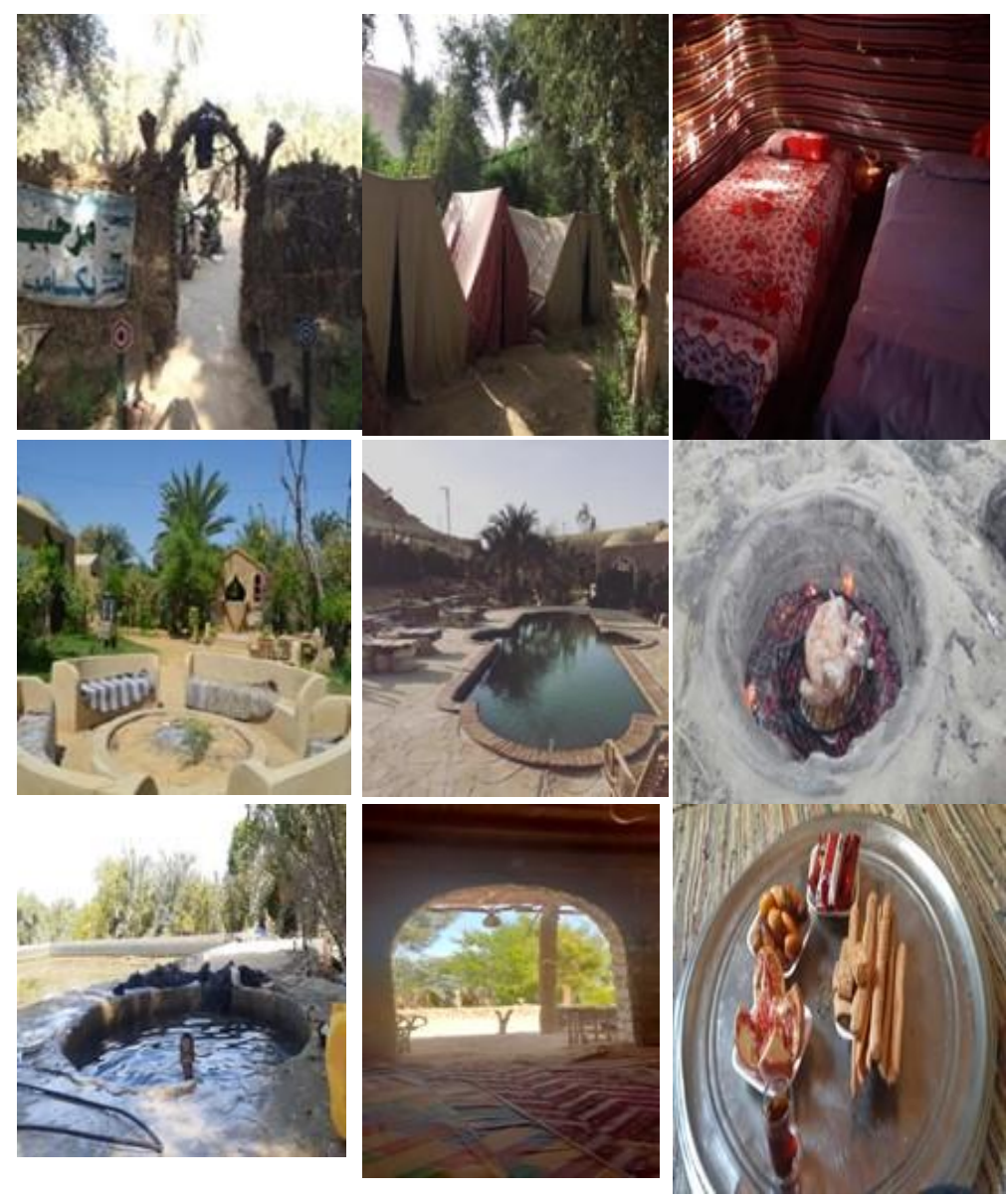

Fig. (9) On -farm Current tourist capabilities Source: The researchers and booking.com 
Potentials of Agricultural Heritage Systems

Tourism (AHST): A case study of date palm uses in gastronomy, Siwa Oasis - Egypt
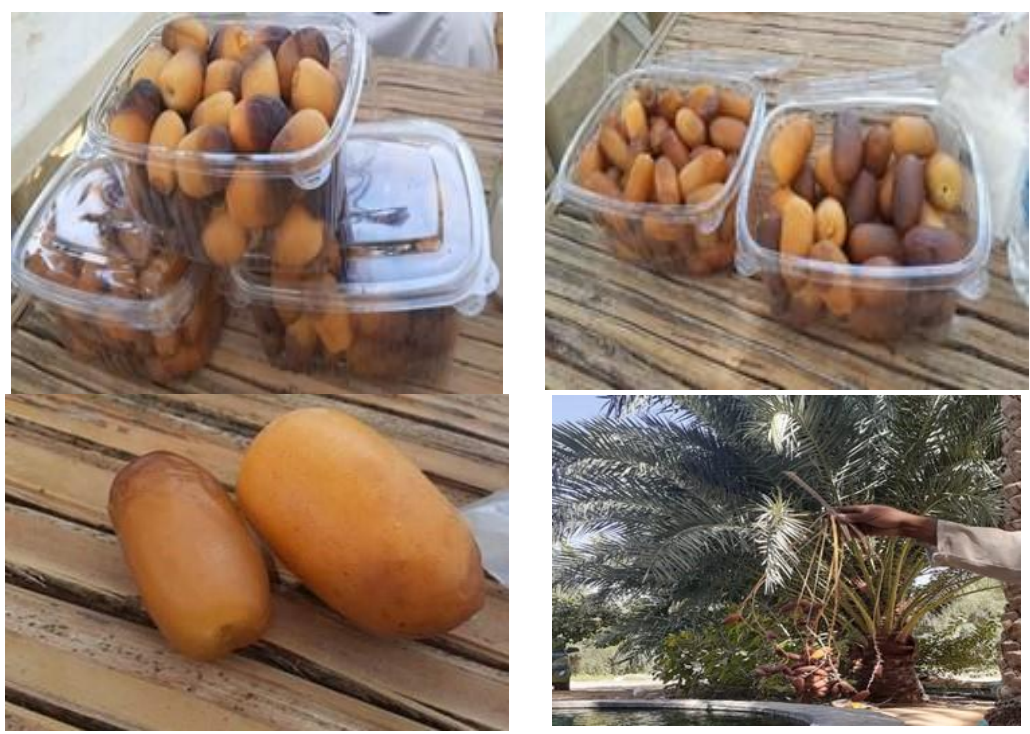

Fig. (10) Date varieties

Source: The researchers 

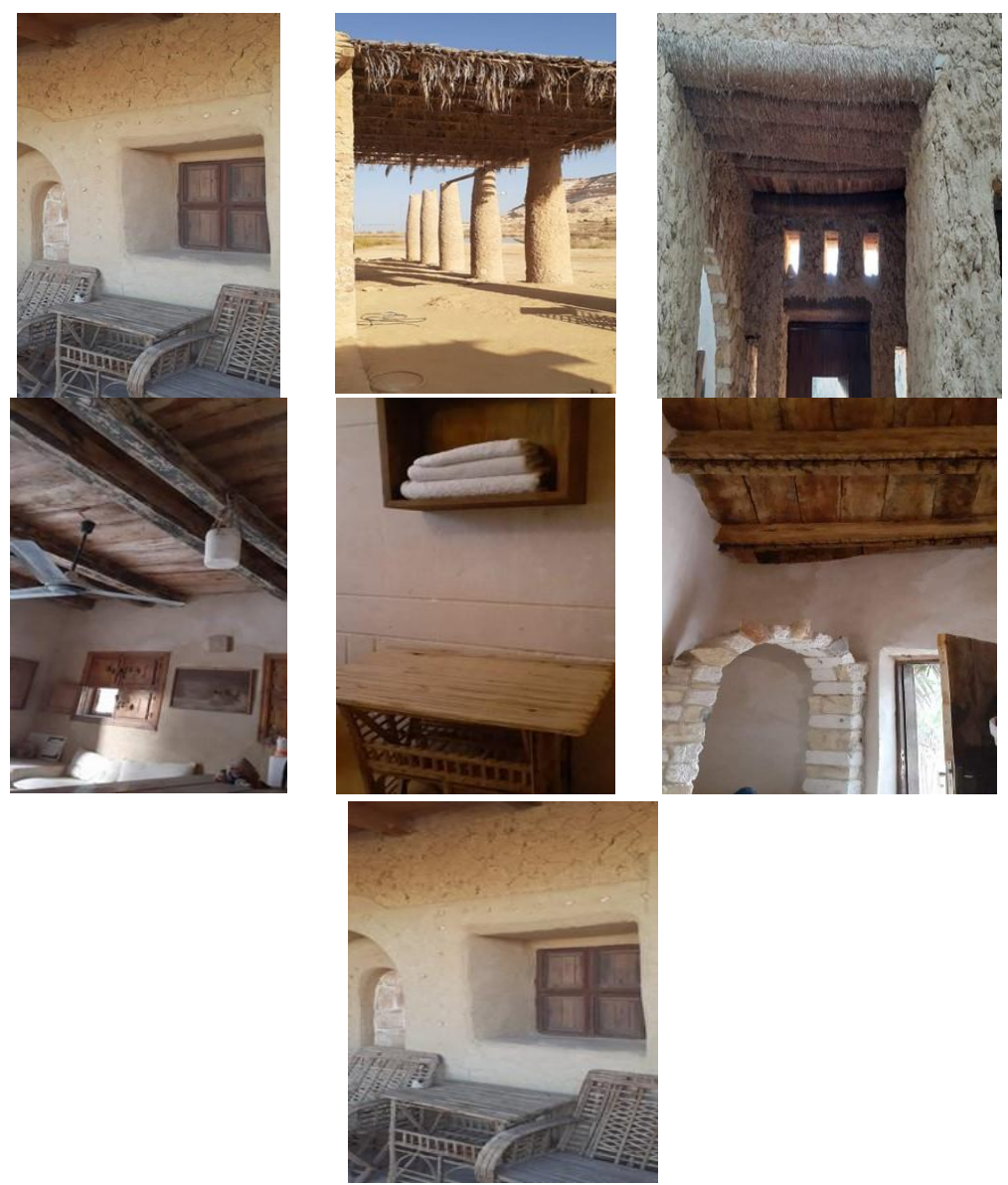

Fig. (11) Using palm in hotels' decoration Source: The researchers 
Potentials of Agricultural Heritage Systems

Tourism (AHST): A case study of date palm uses in gastronomy, Siwa Oasis - Egypt

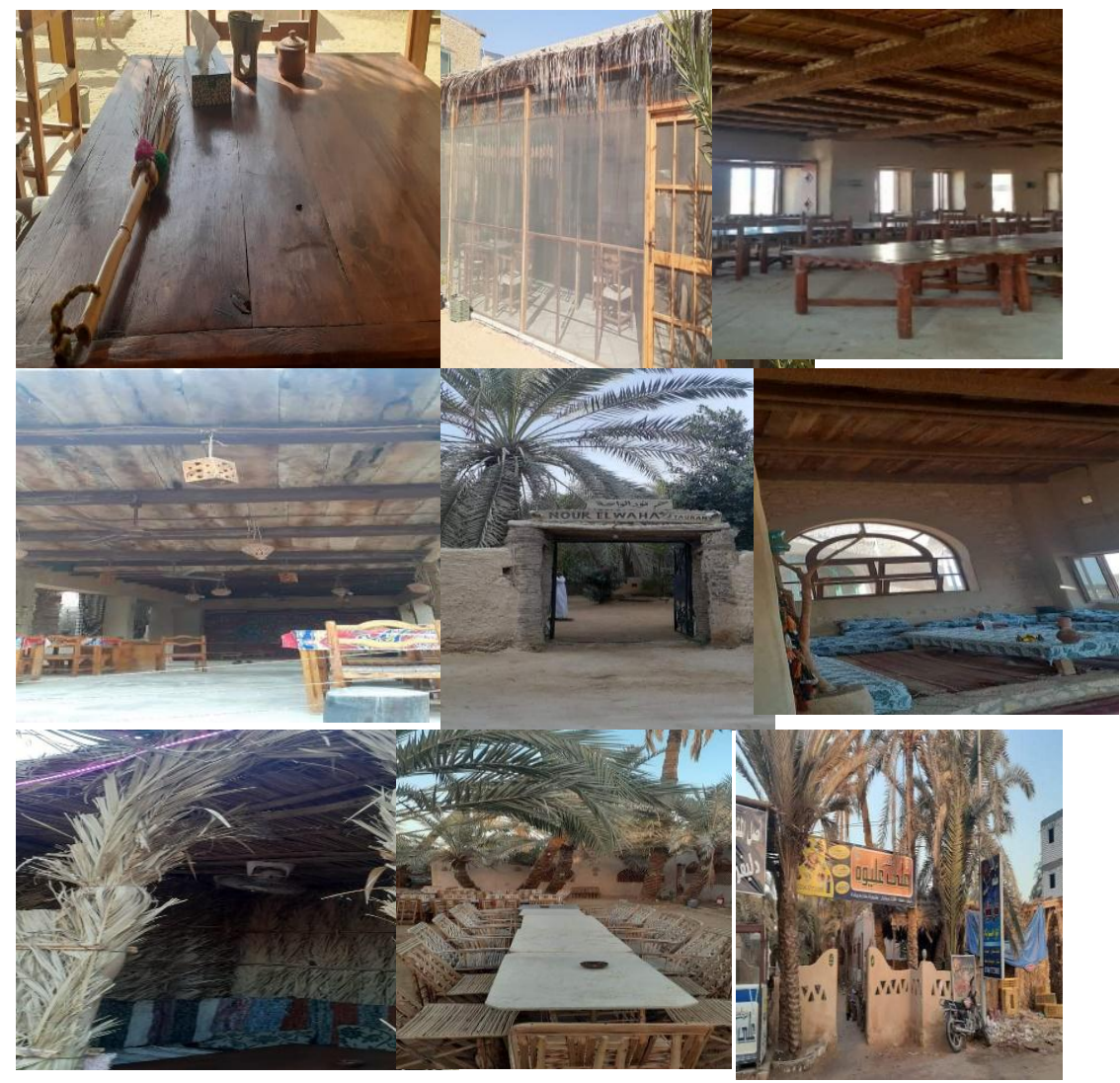

Fig. (12) Using palm in Restaurants' decoration Source: The researchers 


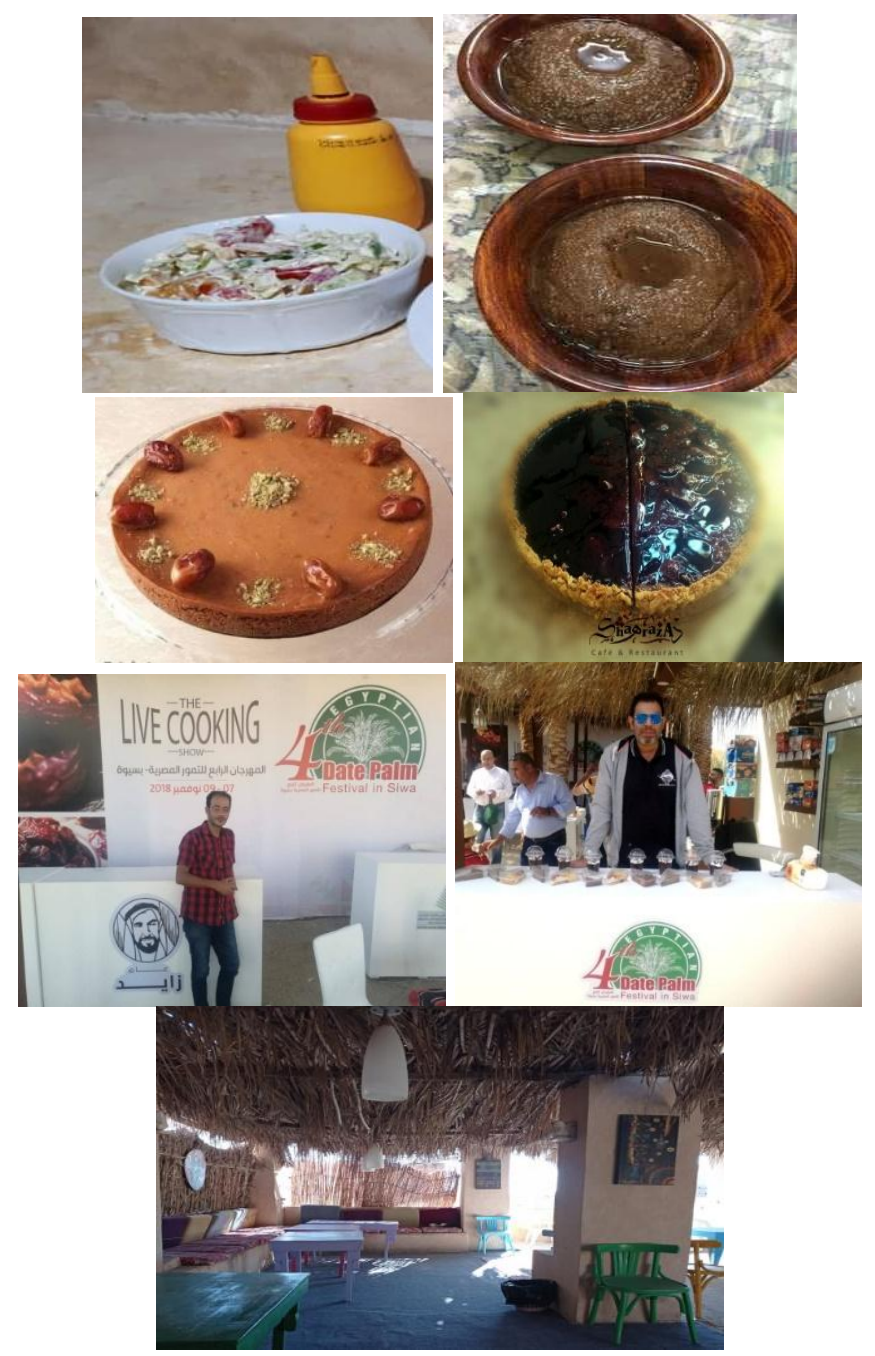

Fig. (13)

Source: The researchers and face book page of Shahrzad Cafe 
Potentials of Agricultural Heritage Systems

Tourism (AHST): A case study of date palm uses in gastronomy, Siwa Oasis - Egypt

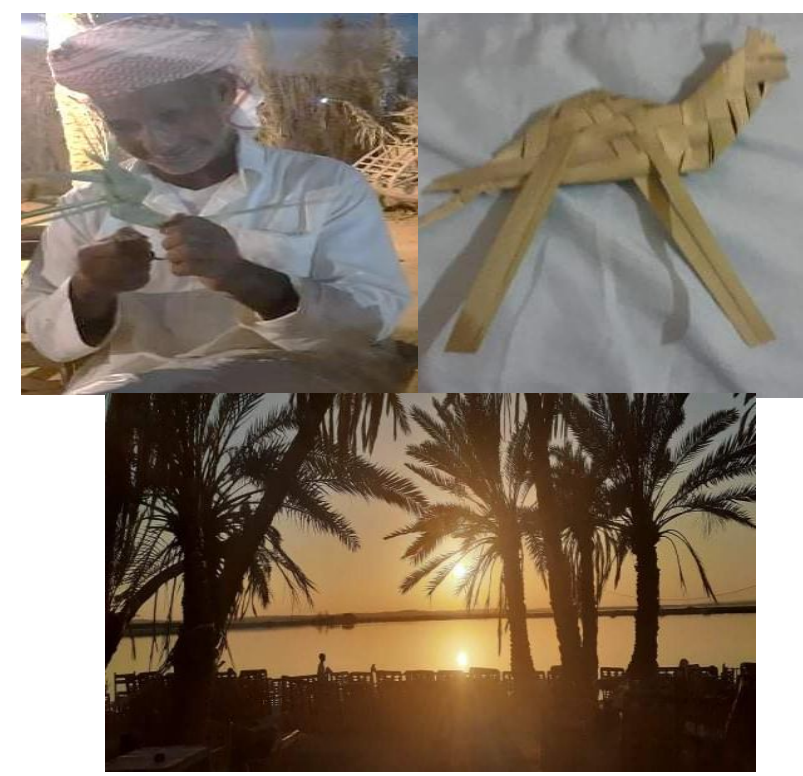

Fig. (14) owner of Fatnas farm and café and his craft products Source: The researchers

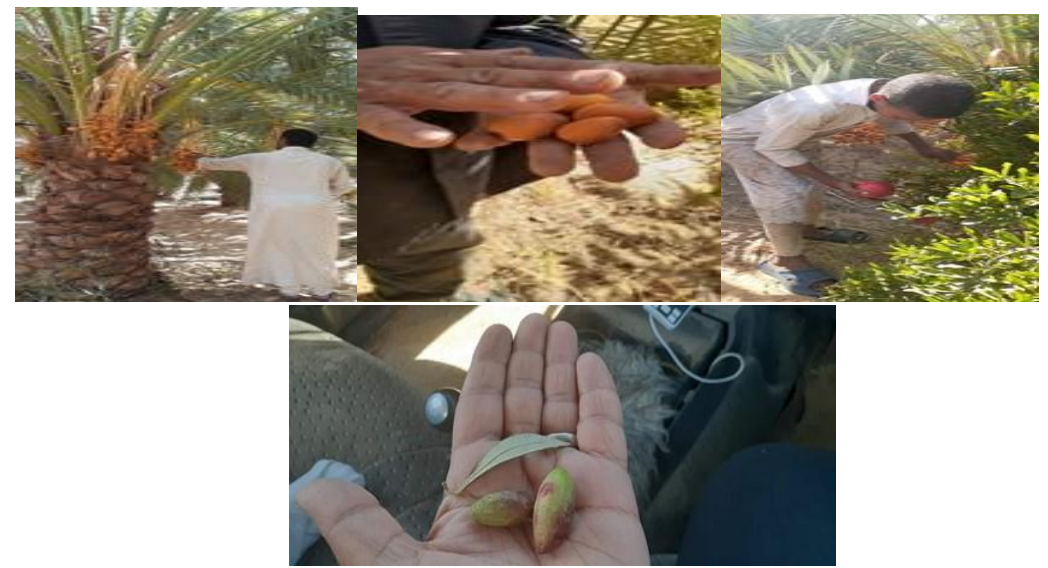

Fig. (15) Fruit picking

Source: The researchers 